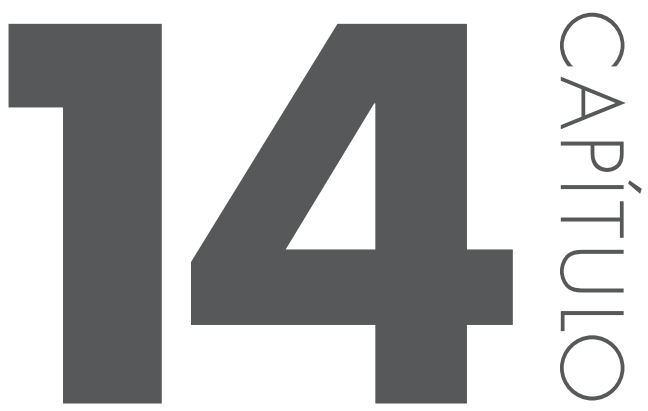

\title{
HISTOLOGIA DO FÍcADO, VIAS BILIARES E PÂNCREAS
}

Carla B. Collares Carla Buzato

Sarah Arana

Carolina Prado de França Carvalho

O pâncreas, o fígado e as vias biliares são órgãos anexos ao tubo digestivo com origem embriológica de brotamentos endodérmicos da porção caudal do intestino anterior em formação. Apesar dessa origem embriológica comum, cada um desses órgãos apresenta organização tecidual e tipos celulares bem distintos que, por sua vez, se relacionam diretamente com as funções que cada um deles desempenha. Este capítulo traz breve introdução sobre os aspectos anatômicos e do desenvolvimento embrionário do pâncreas, fígado e vias biliares, mas tem como enfoque a abordagem dos aspectos da Biologia Celular e Tecidual, traçando um paralelo entre a morfologia e função destes órgãos. Ainda este capítulo cuidasucintamente sobre histopatologia das doenças mais prevalentes que afetam o 
pâncreas e o fígado e relata algumas ideias atuais baseadas no emprego da terapia celular para o tratamento dessas doenças.

\subsection{ANATOMIA E BIOLOGIA DO DESENVOLVIMENTO}

O fígado é a maior glândula do corpo humano, pesando aproximadamente $1500 \mathrm{~g}$ no humano adulto. Ele está situado no quadrante superior direito da cavidade abdominal, e é dividido em quatro lobos (o esquerdo, o direito, o quadrado e o caudado) com a sua região superior e arredondada inserida no domo do diafragma (Figura 14.1).

A vesícula biliar é um órgão piriforme e oco, que ocupa uma fossa rasa na superfície inferior do fígado (Figura 14.1). Consiste de um fundo, um corpo e um colo (pescoço) que se continua com o ducto cístico. Normalmente, ela mede 10 por $4 \mathrm{~cm}$ e tem uma capacidade de $40-70 \mathrm{~mL}$.

O pâncreas é um órgão alongado situado retroperitonealmente na parede posterior da cavidade abdominal, ao nivel da segunda e da terceira vértebras lombares. Este órgão é comumente subdividido em cabeça, corpo e cauda (Figura 14.1). A cabeça está alojada na concavidade em forma de $C$ do duodeno e a parte mais afilada do corpo e a cauda estendem-se transversalmente através da parede posterior do abdome ao hilo do baço. No humano adulto, ele mede $20-25 \mathrm{~cm}$ em comprimento e pesa cerca de 100-150g.

O pâncreas, o fígado e vias biliares são derivados de brotamentos endodér-

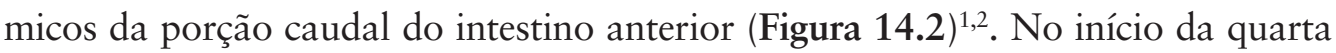
semana de desenvolvimento, há a formação de um divertículo (divertículo hepático) na porção ventral da parede do duodeno que se expande em direção ao mesênquima ventral (septo transverso). O divertículo hepático cresce rapidamente e origina os elementos do parênquima hepático (os cordões ou placas de hepatócitos) e os ductos biliares intra-hepáticos. O estroma hepático, por sua vez, se origina do mesênquima do septo transverso. Na quinta semana do desenvolvimento, surge um divertículo (divertículo cístico), na base do divertículo hepático, que também cresce em direção ao mesênquima ventral e dará origem ao ducto cístico e à vesícula biliar (Figura 14.2). Ainda na quinta semana, outro brotamento da parede do duodeno cresce em direção ao mesênquima dorsal, oposto ao divertículo hepático, formando o brotamento dorsal do pâncreas (Figura 14.2). Poucos dias depois, enquanto este brotamento dorsal se expande em direção ao mesênquima dorsal, outro brotamento, o ventral do pâncreas, surge na região caudal da vesícula biliar em desenvolvimento (Figura 14.2); o ducto principal do brotamento ventral se conecta à extremidade proximal do ducto biliar comum. Quando o duodeno roda para a direita e adquire o formato de um $\mathrm{C}$, o broto pancreático ventral é levado dorsalmente, juntamente 
com o ducto biliar. Este broto logo se localiza posteriormente ao broto pancreático dorsal e, mais tarde, se funde a ele na sexta semana embrionária. Quando os brotos pancreáticos se fundem, os seus ductos se anastomosam. O ducto pancreático principal (ou ducto de Wirsung) se forma a partir do ducto do broto ventral e da parte distal do ducto do broto dorsal. O brotamento pancreático ventral forma o processo uncinado e parte da cabeça do pâncreas, enquanto o brotamento dorsal forma o restante da cabeça, o corpo e a cauda do pâncreas.

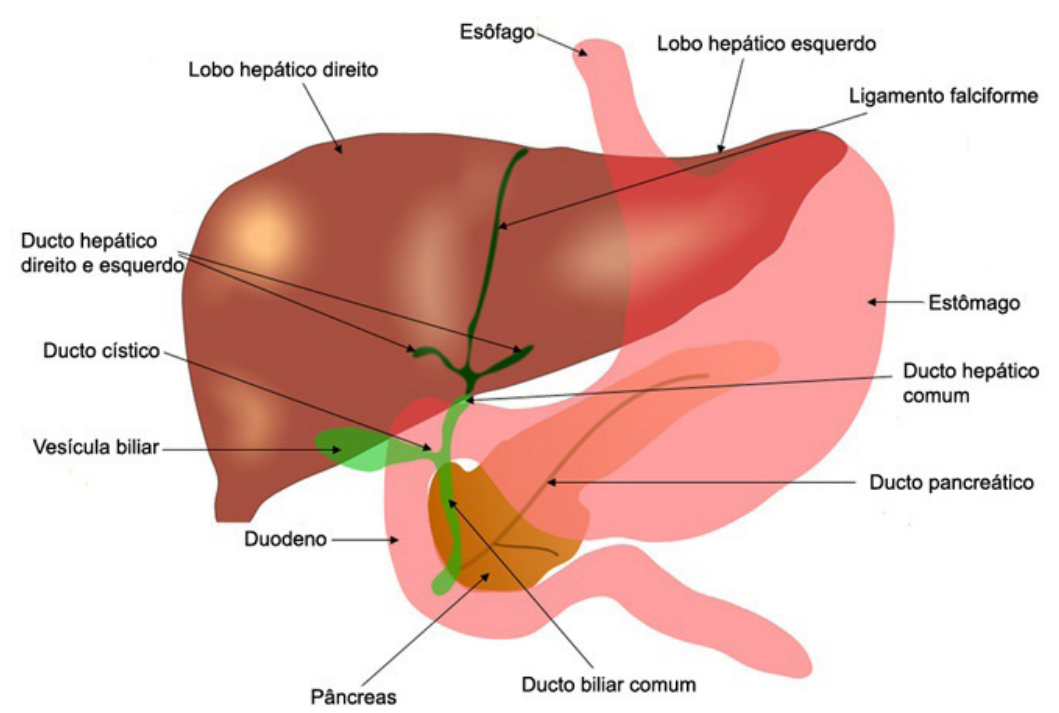

Figura 14.1 - Localização topográfica e anatomia do fígado, das vias biliares e do pâncreas (detalhes no texto). Imagem obtida sob licença de Wikimedia Commons (autor: J.K. Punoose, 2007).

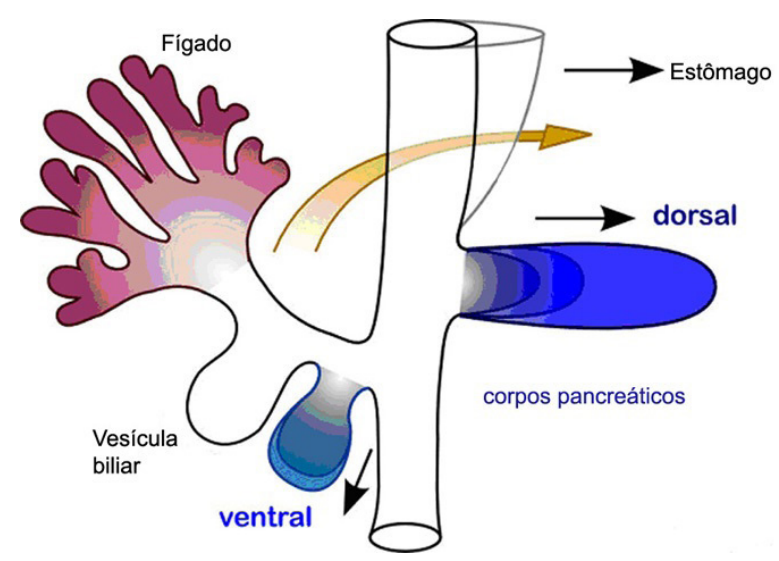

Figura 14.2 - Desenvolvimento embrionário do fígado, das vias biliares e do pâncreas (detalhes no texto). Imagem obtida sob licença de Wikimedia Commons (autor: J. Suckale e M. Solimena, Nature Precedings, 2008). 


\subsection{HISTOLOGIA DO FÍGADO}

O fígado é a maior glândula e o segundo maior órgão do corpo humano, com funções endócrinas e exócrinas. Entre as funções endócrinas, pode-se mencionar secreção de vários hormônios como o fator de crescimento semelhante à insulina ou IGF (insulin-like growth factor), também conhecido como somatomedina, e a eritropoetina. Ainda, essa glândula é responsável pela secreção da maioria das proteínas plasmáticas, como: a albumina, o angiotensinogênio, fatores de coagulação, proteínas carreadoras de ferro, proteínas do sistema complemento e proteínas que participam do transporte plasmático de colesterol e de triglicerídios. Como glândula exócrina, o fígado é responsável pela secreção da bile. Além das funções citadas acima, este órgão efetua centenas de outras funções, todas interligadas e correlacionadas, como, por exemplo, o processamento e o armazenamento dos nutrientes absorvidos pelo trato digestório, o metabolismo e a degradação de hormônios, fármacos e toxinas. Assim, é fácil perceber que o fígado é um órgão vital, com anatomia e histologia bem particulares que garantem essa diversidade funcional.

O fígado é revestido por cápsula de tecido conjuntivo, conhecida como cápsula de Glisson. ${ }^{3,4}$ Cada lobo organiza-se em lóbulos. A vascularização hepática é um elemento da maior importância para garantir a multiplicidade funcional do órgão. O fígado, além de receber sangue arterial através da artéria hepática, recebe cerca de $70 \%$ a $80 \%$ do seu sangue através da veia porta hepática, de modoque quase todo o sangue oriundo do sistema digestório e do baço drena para o fígado. Ambos os vasos sanguíneos alcançam o fígado através do hilo, também conhecido como porta hepatis, com origem na qual se ramificam profusamente até que o sangue arterial e venoso se misture na ampla rede capilar hepática dos lóbulos, constituída pelos sinusóides hepáticos (Figura 14.3). Dos sinusoides, o sangue drena para a veia central e desta para as veias hepáticas, as quais drenam para a veia cava inferior.

Uma vez nos sinusoides, o sangue entra em íntimo contato com a principal célula parenquimatosa do lóbulo hepático, o hepatócito, relacionado com a maioria das funções já citadas (Figura 14.3).

Como já comentamos, a principal excreção exócrina do fígado é a bile, a qual é transportada para a vesícula biliar, pelos ductos biliares ou hepáticos, direito e esquerdo, os quais se unem para formar o ducto hepático comum (Figura 14.1). Os ductos biliares deixam o fígado por via do hilo e seus ramos menores intra-hepáticos são observados associados aos ramos da veia porta e da artéria hepática. 


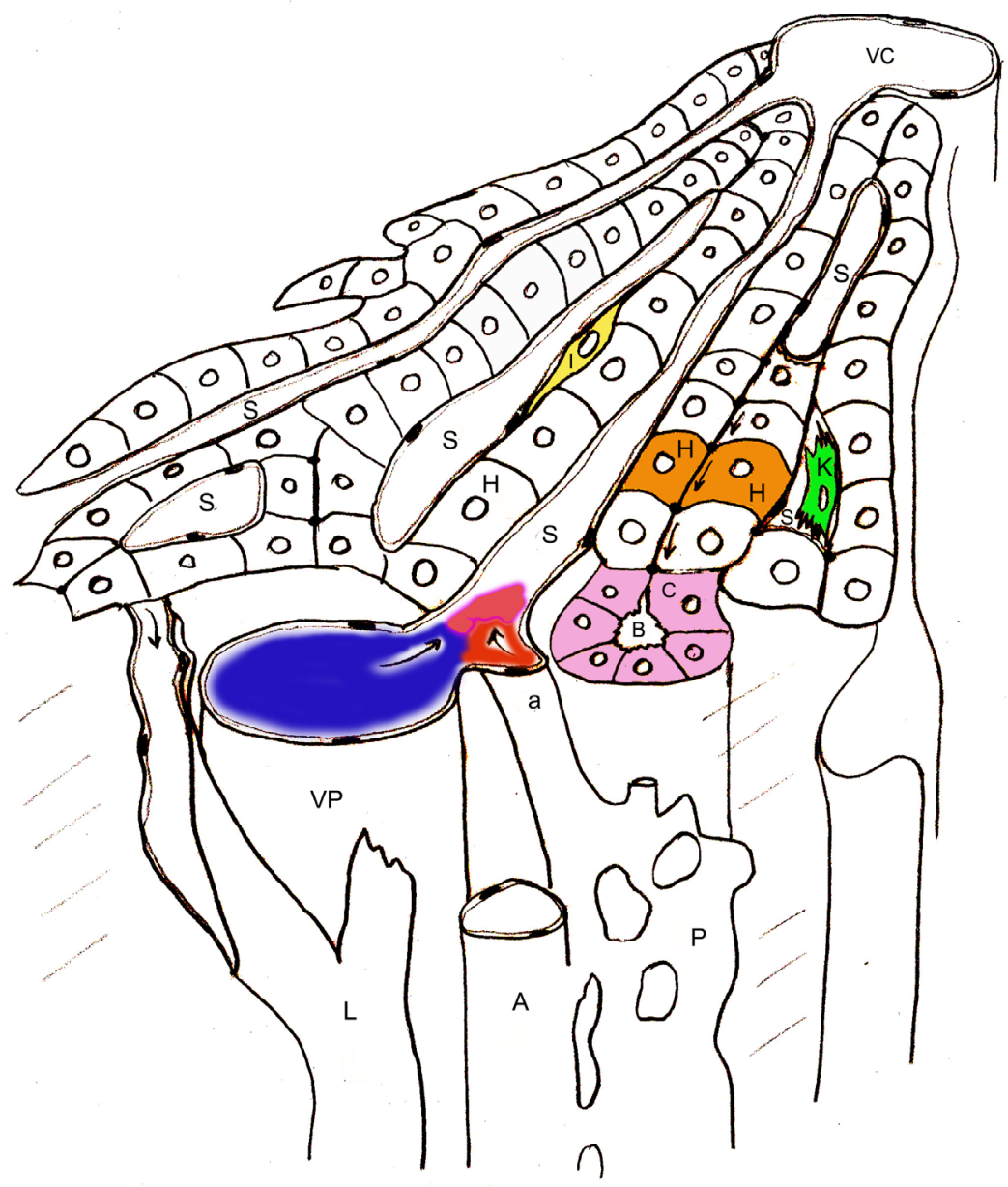

Figura 14.3 - Representação esquemática de parte do lóbulo hepático e do espaço porta em fígado humano. Notar que os hepatócitos ( $\mathrm{H}$, em laranja) apresentam uma superfície voltada para 0 canalículo biliar (seta curta) e outra superfície voltada para o capilar sinusoide ( $S$ ); repare que o sangue arterial (em vermelho) e 0 venoso (em azul) se misturam nesses capilares. Célula de Kupffer (K, em verde) é observada no lúmen do capilar sinusoide e, entre o capilar e o hepatócito, no espaço de Disse, se localiza a célula estrelada ou de Ito (I, em amarelo). No espaço porta, notam-se vasos linfáticos (L) que drenam o liquido intersticial oriundo do lóbulo hepático (fluxo indicado pela seta), ramo da artéria hepática (A) que se ramifica originando artérias menores (a), que, por sua vez, originam o plexo capilar $(P)$ que irriga o ducto biliar (B), delimitado pelos colangiócitos (C, em rosa) e os outros elementos do espaço porta. 
Finalmente, quanto ao arranjo geral do fígado, este órgão tem um estroma escasso. Esse é representado pelo tecido conjuntivo perilobular e perivascular e uma rede complexa de fibras de colágeno tipo III (fibras reticulares) que forma um arcabouço de sustentação dos cordões de hepatócitos, que, como expresso constitui o principal elemento do parênquima desta glândula.

\subsubsection{LÓBULO HEPÁTICO}

Há três modelos conceituais empregados atualmente para definir a estrutura organizacional do parênquima hepático, os quais levam em conta aspectos distintos, meramente estruturais ou funcionais. Assim, esses modelos são: 1) o conceito de lóbulo hepático clássico, o qual se baseia exclusivamente em parâmetros estruturais; 2) o conceito do lóbulo portal, esteado na direção do fluxo biliar no fígado, ou seja, a via de drenagem da bile do canalículo para o ducto biliar; e 3) o conceito de ácino hepático que considera o gradiente de distribuição de oxigênio/ nutrientes ao longo dos sinusóides hepáticos (Figura 14.4). ${ }^{3,4}$

Iniciaremos este item com a descrição pormenorizada do lóbulo hepático clássico, uma vez que este entendimento será muito útil para compreender os outros dois modelos que têm por base aspectos funcionais. Cada lóbulo hepático clássico é formado por cordões, ou placas, de hepatócitos entremeados por capilares sinusoides (Figura 14.5). ${ }^{3,4} \mathrm{Em}$ alguns mamíferos, os limites destes lóbulos são bem demarcados por uma camada de tecido conjuntivo; nestes casos o arranjo hexagonal dos lóbulos hepáticos é facilmente percebido (Figura 14.5b). Em humanos, contudo, esta forma hexagonal não é facilmente identificada, porque a delimitação conjuntiva é delicada e incompleta (Figura 14.5a). Em alguns locais da periferia dos lóbulos, precisamente nos cantos do hexágono, se nota maior quantidade de tecido conjuntivo e nele ramos da artéria hepática, da veia porta e do ducto biliar. Nestes locais, também é possível encontrar vasos linfáticos e nervos. Essas regiões são denominadas espaço porta e como se observa um ramo da artéria hepática, um ramo da veia porta e um ramo do ducto biliar nesse espaço, o conjunto destas estruturas recebe a denominação de tríade portal (Figuras 14.5c). 


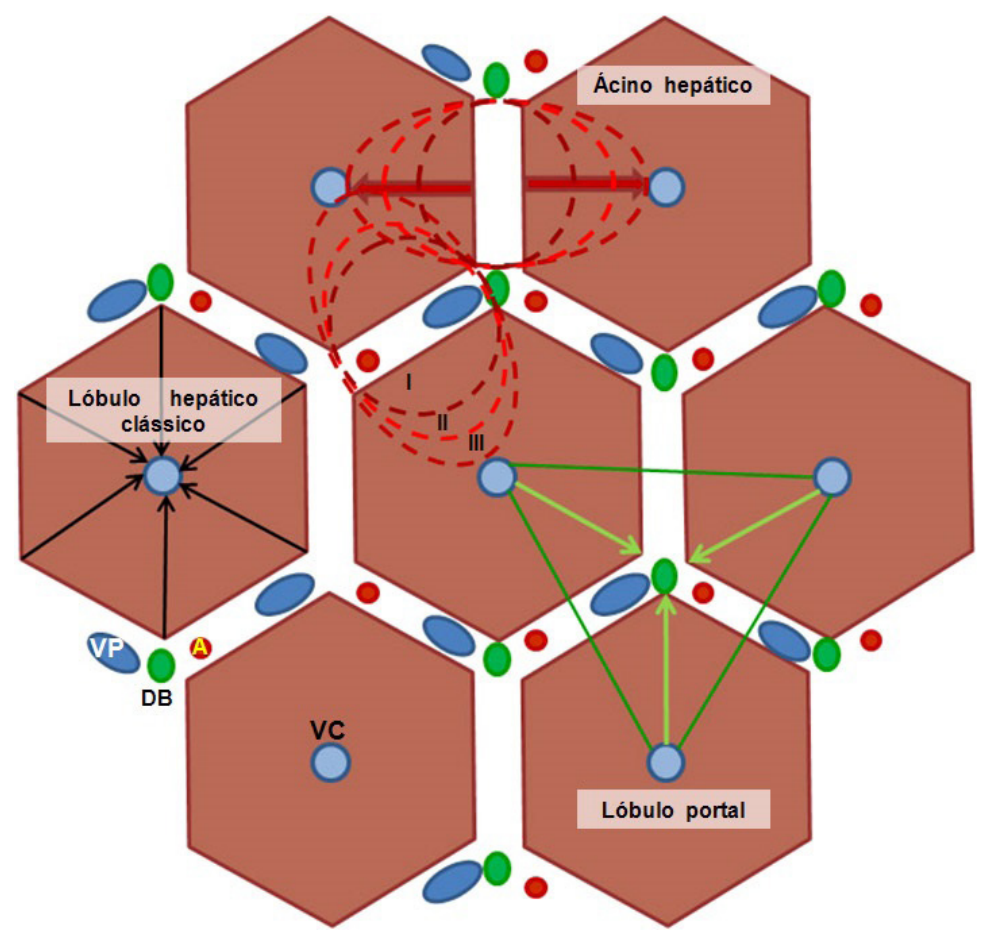

Figura 14.4 - Esquema ilustrativo dos modelos de organização estrutural e/ou funcional do fígado. No lóbulo hepático clássico, que se baseia no arranjo estrutural de elementos hepáticos, a região periférica do lóbulo faz limites com lóbulos adjacentes e com 0 espaço porta, no qual se notam ramos da veia hepática (VP), ramos do ducto biliar (DB) e ramos da artéria hepática (A); enquanto 0 centro do lóbulo clássico é marcado pela veia central (VC). 0 lóbulo portal, por sua vez, leva em consideraçáo o fluxo da bile; 0 centro do lóbulo é representado pelo ducto biliar e suas extremidades delimitadas pelas veias centrais de três lóbulos clássicos vizinhos. 0 ácino hepático baseia-se no suprimento sanguíneo dos hepátócitos, ou seja, na qualidade do sangue, quanto à quantidade de nutrientes e oxigênio, que nutre essas células: a zona I, que fica próxima ao espaço porta, é rica em oxigênio e nutrientes; a zona III, próxima à veia central, é pobre em oxigênio; e a a zona ll é intermediária em relação à quantidade de oxigênio e nutrientes. 

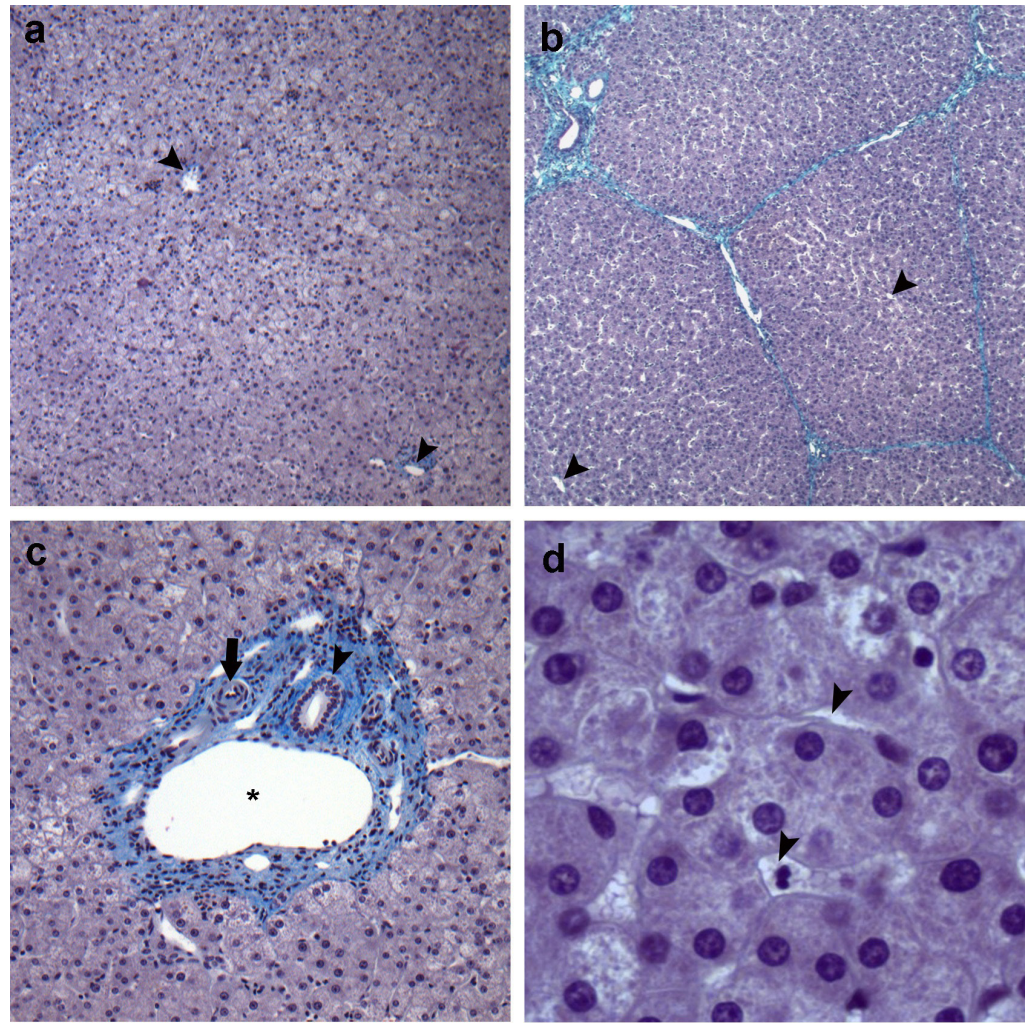

Figura 14.5 - Fotomicrografias de corte histológico de fígado humano corado com tricrômico de Masson mostrando o lóbulo hepático (a, aumento pequeno), um detalhe do espaço porta (c, aumento médio) e dos cordões de hepatócitos entremeados por capilares sinusoides ( $d$, sinusoides indicados por cabeças de seta; aumento grande). Em b, histologia do fígado de porco (coloração com Tricrômico de Masson) que mostra uma lobulação bem definida. Em a e b, cabeça de seta indica a veia central. Em c, asterisco indica ramo da veia porta; seta indica ramo da artéria hepática; cabeça de seta indica ducto biliar.

A partir do espaço porta, os ramos da artéria hepática e da veia porta confluem para a rede de capilares sinusoides, onde o sangue venoso se mistura ao sangue arterial (Figura 14.3). No sentido inverso, do interior do lóbulo hepático, canalículos biliares confluem para formar o ductulo biliar e assim conduzir a bile formada no interior do lóbulo para o ducto biliar no espaço porta. As funções endócrinas e de secreção da bile são desempenhadas pelo hepatócito, célula volumosa e polarizada que apresenta seu pólo apical direcionado para o canalículo biliar, local de secreção da bile, e seus domínios basolaterais voltados para o capilar sinusóide. O centro do lóbulo hepático mostra um vaso venoso para onde confluem os capilares sinusoides; por essa razão, a parede dessa veia é interrompida pela abertura desses sinusoides (Figura 14.3). Por estar no centro do lóbulo, 
este vaso denomina-se veia central, ou centrolobular (Figura 14.3 a 14.5). Assim, ao se observar um corte transversal do lóbulo hepático, em microscopia de luz com a utilização de objetiva de pequeno aumento, percebe-se que as placas de hepatócitos se organizam de forma radial da periferia em direção à veia central (Figura 14.3 a 14.5).

A veia central, ao abandonar o lóbulo, conflui para a veia hepática sublobular; o local anatômico onde isto ocorre é distinto do lugar onde está a veia porta. Assim, em humanos, é possível identificar histologicamente estes dois ramos venosos, pois ramos da veia porta sempre estarão compondo a tríade portal, enquanto a veia hepática segue isolada em septos de tecido conjuntivo até deixar o fígado e confluir para as veias supra-hepáticas, que por sua vez, desembocam na veia cava inferior.

Quanto ao lóbulo portal (Figura 14.4), ele inclui porções de lóbulos hepáticos vizinhos cujos canalículos biliares drenam para o mesmo ducto biliar, que, por sua vez, se encontra no espaço porta comum a esses lóbulos. Assim, o centro do lóbulo portal é o ducto biliar, tendo por essa razão um espaço porta como centro e uma veia central a demarcar as extremidades de um triângulo (Figura 14.4). ${ }^{4,5}$ Este modelo de lóbulo é raramente empregado.

O modelo do ácino hepático (Figura 14.4), por outro lado, é bastante empregado, principalmente em avaliações histopatológicas, devido ao seu critério funcional que se baseia na unidade microcirculatória do fígado, relacionada com os ramos terminais da circulação aferente. ${ }^{4,5}$ Assim, o conceito de ácino hepático reflete a posição que os hepatócítos ocupam em relação ao seu suprimento sanguíneo. Os hepatócitos mais próximos ao espaço porta, onde se encontram os ramos da artéria hepática e veia porta, estão em contato, por via dos capilares sinusoides, com sangue mais oxigenado e com maior quantidade de nutrientes. A primeira região do ácino hepático é denominada zona 1 e equivale à região perilobular no conceito do lóbulo clássico. Já os hepatócitos mais distantes do espaço porta, ou seja, aqueles situados perto da veia central, recebem menor concentração de oxigênio e o mesmo se dá com os nutrientes; esta região do ácino é denominada zona 3 e equivale à região centrolobular no conceito de lóbulo clássico. O sangue circulante na zona 3 contém maior concentração de dejetos metabólicos, os quais foram eliminados pelos hepatócitos situados nas zonas anteriores. A zona intermediária é conhecida como zona 2.

Em função desse distinto gradiente de oxigênio e de vários outros elementos no suprimento sanguíneo, os hepatócitos apresentam uma nítida heterogeneidade funcional em relação à zona do ácino hepático que ocupam. ${ }^{5}$ Assim, hepatócitos localizados na zona 1, preferencialmente, catalisam o metabolismo oxidativo, o metabolismo energético de ácidos graxos e aminoácidos, e estão envolvidos com 
a síntese de ureia, com a gliconeogênese, e a formação de bile. Os hepatócitos da zona 3 estão preferencialmente envolvidos com a glicólise, a glicogênese, a liponeogênese, a formação de corpos cetônicos, a formação de glutamina, e o metabolismo de xenobióticos.

Essa heterogeneidade dos hepatócitos também implica em diferenciada suscetibilidade aos agentes tóxicos e lesivos ao fígado de maneira geral, por exemplo: no caso de uma intoxicação, haverá maior concentração dessa substância na zona 1. Assim os hepatócitos dessa região serão mais comprometidos; por outro lado, em uma situação de redução dos níveis de oxigênio, os hepatócitos da zona 3 se mostrarão mais comprometidos. Pelo exposto, fica fácil compreender a importância do conceito do ácino hepático na histopatologia hepática.

\subsubsection{HEPATÓCITO}

Os hepatócitos, no fígado humano, geralmente apresentam de 20 a $30 \mu \mathrm{m}$ de diâmetro, são células poliédricas, dotadas de um núcleo central com cromatina descondensada, contendo 1-2 nucléolos evidentes no seu interior; ainda apresentam um citoplasma amplo e eosinofilico, devido principalmente ao grande número de mitocôndrias (Figura 14.5). São células polarizadas que apresentam seis ou mais superfícies, ou faces, que se relacionam com o canalículo biliar, com a membrana de hepatócitos vizinhos e com o sinusóide, sendo que nesse caso existe um espaço entre estas duas estruturas, que é denominado espaço perissinusoidal ou espaço de Disse (Figura 14.6c)..$^{3-5}$

Por ser uma célula multifuncional, todas as organelas citoplasmáticas estão bem representadas nos hepatócitos (Figura 14.6a). O retículo endoplasmático rugoso é abundante e está diretamente relacionado com a síntese de proteínas plasmáticas e lipoproteínas. O retículo endoplasmático liso está envolvido com a síntese de ácidos biliares, com a síntese de lipoproteínas e de colesterol e, ainda, contém enzimas relacionadas com os processos de detoxificação, mediante os quais, moléculas lipossolúveis são convertidas em moléculas hidrossolúveis. As mitocôndrias são numerosas, cerca de 1000 ou mais em cada célula, e de particular importância em função das variadas atividades metabólicas do hepatócito, como a detoxificação de espécies reativas de oxigênio (radicais livres) sob a ação de enzimas mitocondriais. O complexo de Golgi também se destaca, dada a sua participação na secreção das proteínas plasmáticas e lipoproteínas. Grânulos de glicogênio se acumulam no citoplasma, porém a quantidade armazenada varia com o nível de açúcar no sangue; quando esse nível cai, o glicogênio é degradado em glicose que é liberada para os sinusoides. Finalmente, lisossomos e outras vesículas da via endocítica também são 
observados. Os lisossomos podem conter lipofuscina, constituída por fosfolípides e proteínas e resulta da digestão incompleta dos restos celulares.
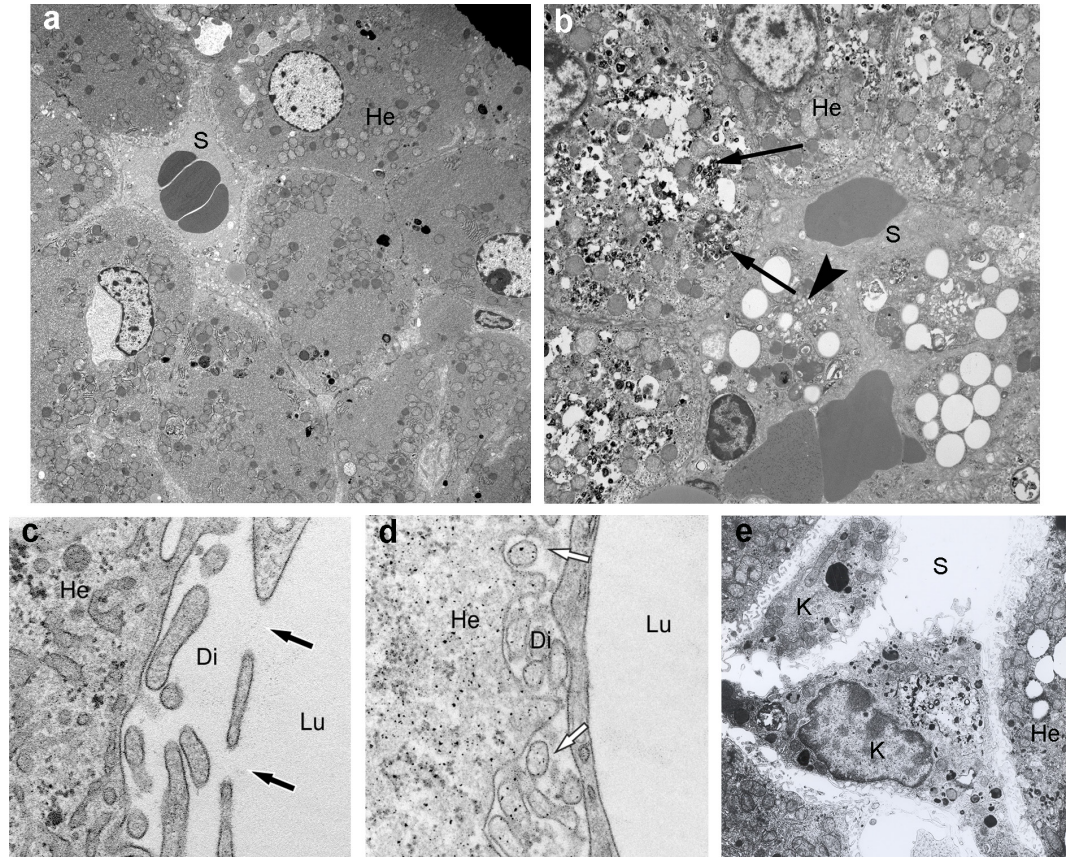

Figura 14.6 - Em a, fotomicrografia ultraestrutural do fígado, mostrando hepatócitos (He) entremeados por um capilar sinusóide (S), no interior do qual é possível ver hemácias. Em b, hepatócitos (He) repletos de autofagolisossomos (setas) em modelo animal de esteatose hepática não alcoólica. Ainda, é possível observar em b, capilar sinusoide (S) e células de lto (cabeça de seta) contendo gotículas lipídicas no seu citoplasma. Em c, fotomicrografia ultraestrutural (em grande aumento) mostrando detalhe do espaço de Disse (Di) entre o hepatócito ( $\mathrm{He}$ ) e a parede endotelial interrompida por fenestras (setas em preto) no sinusóide (Lu, luz do sinusóide). Em d, imagem mostra ausência de fenestras na parede do sinusóide e acúmulo de material granular eletrondenso (setas em branco) no espaço de Disse (Di), o que está associada com um quadro de esteatose e fibrose hepática em modelo animal. Em e, fotomicrografia de células de Kupffer (K) no interior do sinusoide (S). Imagens a e b reproduzidas do periódico PLoS ONE 10(5):e0124173, 2015. doi:10.1371/journal.pone.0124173,(autores: Liang T. et al.), sob licença da Creative Commons. Imagens c e d reproduzidas do periódico PLoS ONE 9(12): el15005, 2014. doi:10.1371/journal.pone.0115005,(autores: Herrnberger L. et al.), sob licença da Creative Commons. Imagem d foi gentilmente cedida pelo Prof. Dr. Paulo P. Joazeiro.

$\mathrm{Na}$ região de contato intercelular entre hepatócitos, são observadas, por microscopia eletrônica de transmissão, junções intercelulares do tipo aderente, de oclusão e desmossomos que permitem uma adesão firme entre essas células, além de junções comunicantes que constituem uma via de comunicação intercelular. ${ }^{6}$ À 
semelhança do que acontece com outros tipos celulares, essas especializações da membrana plasmática são muito importantes para a homeostasia funcional do hepatócito; tanto que certas doenças hepáticas, agudas (induzidas por agentes xenobióticos) ou crônicas (cirrose, fibrose e hepatite), estão frequentemente associadas com diminuição significativa na expressão das proteínas estruturais dessas junções ou com inibição da formação dessas junções intercelulares, respectivamente. ${ }^{6}$

\subsubsection{ESPAÇO DE DISSE E ESTRUTURA DOS SINUSOIDES HEPÁTICOS}

O hepatócito, em sua superfície voltada para o espaço perissinusoidal, apresenta microvilos, os quais ampliam a área de membrana celular já que numerosas moléculas e compostos serão absorvidos do sangue ou secretados para esse compartimento, a partir dos sinusóides (Figura 14.6c). Quatro tipos celulares estão regularmente relacionados aos sinusoides e no espaço de Disse: 1) as células endoteliais dos sinusóides; 2) os macrófagos, os quais neste órgão são denominados células de Kupffer; 3) as células estreladas armazenadoras de lipídio, também conhecidas como células de Ito; e 4) os linfócitos, do tipo "natural killer" (NK cells) também conhecidos como "pit cell", células que estão aderidas à margem luminal dos sinusoides e que correspondem a uma população de linfócitos específica do fígado. ${ }^{3-5}$

As células endoteliais apresentam o citoplasma bem delgado, com numerosas fenestras de aproximadamente $170 \mathrm{~nm}$ de diâmetro sem diafragma (Figura 14.6c)..$^{5}$ As fenestras são estruturas dinâmicas, cujo diâmetro pode ser modificado pela pressão do sangue luminal, por substâncias vasoativas, drogas, toxinas e, ainda, doenças e envelhecimento. Esse mecanismo de controle parece envolver os microfilamentos de actina do citoesqueleto. As células endoteliais dos sinusóides hepáticos, assim como a de outros capilares, são também secretoras e liberam: interleucina 1, interleucina 6, interferon, endotelina e óxido nítrico. Assim, as células endoteliais participam da regulação da pressão do fluxo sanguíneo e, em conjunto com a célula de Kupffer, dos mecanismos de defesa do fígado. Essas células geralmente não apresentam lâmina basal ou esta se mostra interrompida; esta adaptação tem o propósito de facilitar o trânsito de solutos e partículas para o espaço de Disse, facilitando o acesso desse material aos hepatócitos e às células de Ito. Escassas fibrilas de colágeno podem ser encontradas no espaço de Disse, suportando os sinusoides e os hepatócitos, mas, em geral, o material colagênico e outras proteínas de matriz extracelular são escassos nesse local.

As células de Kupffer apresentam, em geral, uma superfície irregular, com numerosos microvilos, filopódios ou lamelopódios que geralmente se projetam para o espaço luminal dos sinusoides (Figura 14.6e). ${ }^{5}$ Estes macrófagos têm um 
importante papel na remoção de partículas, células e substâncias tóxicas, ou estranhas que alcancem o trato portal, particularmente originárias do intestino. Estas células também secretam uma série de substâncias vasoativas ou citotóxicas, como radicais livres, citocinas, interferon, fator ativador de plaqueta e enzimas lisossomais, os quais podem estar envolvidos na defesa do hospedeiro ou em alguns processos patológicos no fígado.

As células estreladas, que recebem várias denominações na literatura médica como células armazenadoras de gordura, células de Ito ou lipócitos, apresentam seu citoplasma com numerosas gotículas de lipídio, e representam o principal sítio de estocagem de retinoides no organismo, como a vitamina A (Figura 14.6b). ${ }^{5}$ Estas células possuem processos citoplasmáticos que se estendem pelo espaço de Disse e podem envolver e circundar a parede do capilar sinusóide, morfologia que justifica a denominação de células estreladas. Estas células também apresentam grande quantidade de microtúbulos e microfilamentos e estão em estreita associação com terminações nervosas, sendo que tais características, somadas à constatação de que apresentam atividade contrátil, indicam sua participação na regulação do fluxo sanguíneo dos sinusoides.

Como mencionado anteriormente, o fígado humano apresenta uma quantidade relativamente escassa de tecido conjuntivo (estroma). Contudo, algumas injúrias hepáticas, como as induzidas por consumo crônico de álcool, infecção viral, exposição às toxinas e drogas, podem resultar em aumento dos componentes estromais levando à fibrose hepática (Figura 14.7c). ${ }^{5,7} \mathrm{Na}$ fibrose, os componentes de matriz, incluindo colágeno tipo I, podem se acumular no espaço de Disse resultando em um processo conhecido como "capilarização" dos sinusóides. Este processo, que envolve desde alterações no endotélio vascular, como perda de fenestrações e formação de uma verdadeira membrana basal, até mudanças nas interações célula-célula e célula-matriz nos sinusóides hepáticos, nitidamente compromete o transporte de substâncias entre esses compartimentos, hepatócito e sinusóide, e prejudica a função hepática de maneira geral (Figuras 14.6d e 14.7).

A secreção de várias citocinas, como o fator de crescimento transformante $\beta$ (TGF $\beta$ ), pela célula de Kupffer e pelo próprio hepatócito, que ocorre nessas injúrias hepáticas, modula o comportamento das células estreladas, processo denominado ativação. ${ }^{5,7}$ Nesse processo, as células estreladas diminuem o armazenamento de lípidios, proliferam e se tornam engajadas na síntese de proteínas de matriz extracelular, com este fenótipo estas células são denominadas miofibroblastos (Figura 14.7e). ${ }^{5}$ Com o progresso da doença, ocorre o aumento da resistência vascular, associado à diminuição do lúmen dos sinusóides pela contração dos processos citoplasmáticos dos miofibroblastos. O aumento dessa resistência vascular se reflete na hipertensão portal associada à cirrose. Assim, devido à im- 
portância da participação dos miofibroblastos nos processos de injúrias hepáticas, estas células são atualmente alvo de muitos estudos voltados para o controle da cirrose hepática.

Em várias condições patológicas, associadas ou não com o consumo excessivo de álcool (como, por exemplo, na hepatite viral ou na intoxicação por certas drogas e metais, na obesidade e na diabetes), os hepatócitos podem acumular grande quantidade de lipídios, levando ao quadro conhecido como esteatose hepática (ou "fígado gorduroso"). ${ }^{7}$ A esteatose hepática pode preceder ou estar associada à fibrose hepática nessas condições (Figura 14.7b).
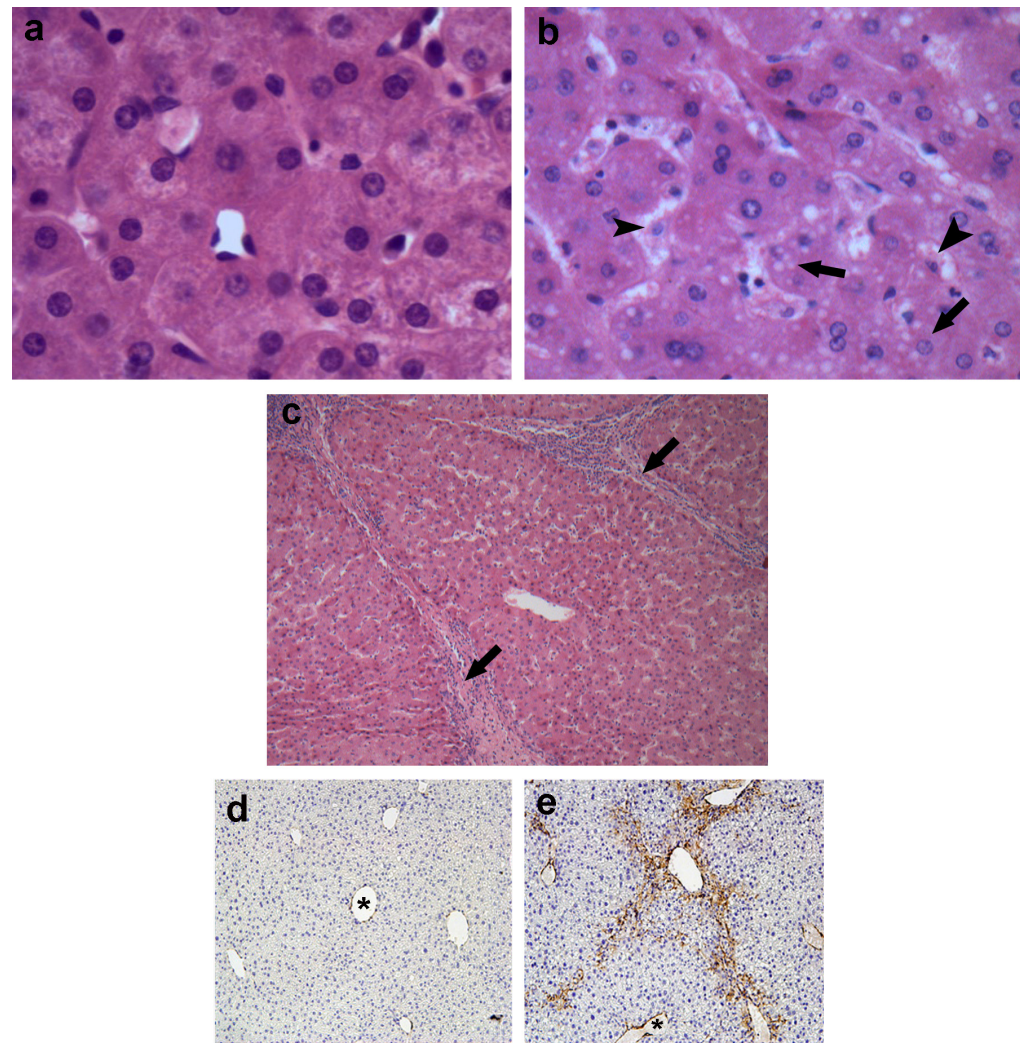

Figura 14.7 - Fotomicrografias de cortes histológicos, corados com hematoxilina e eosina, de fígado humano normal (a) e um com esteatose (em b, setas indicam hepatócitos com gotículas de lipídios e cabeças de seta, células de Kupffer) e fibrose (em c, seta indica acúmulo de tecido conjuntivo perilobular). Em de e, cortes histológicos de fígado processados para imuno-histoquímica para actina alfa de músculo liso (em marrom), marcador de miofibroblastos, mostrando a ativação das células estreladas no fígado fibrótico (em e, marcą̧ão na região perilobular e ao redor da veia centrolobular) mas não no fígado normal (d), em modelo animal. Asteriscos em d e e indicam veia centrolobular. Imagens $\mathrm{d}$ e e reproduzidas do periódico PLoS One 8(7): e69114, 2013. doi:10.1371/journal.pone.0069114 (autores: Chiang D.J. et al.), sob licença da Creative Commons. 


\subsubsection{SECREÇÃO DE BILE, CANALíCULOS E DUCTOS BILIARES INTRA-HEPÁTICOS}

Diariamente, cerca de 0,5 a 1,0 litro de bile é lançada no duodeno. Essa secreção contém pigmentos (bilirrubina direta ou conjugada), sais biliares (ácido cólico, desoxicólico, litocólico e quenodesoxicólico), proteínas, fosfolipídios, colesterol e eletrólitos. A bilirrubina indireta (não hidrossolúvel) não é produzida pelo hepatócito, é oriunda do sangue drenado do baço e resulta do fracionamento de hemoglobina por macrófagos esplênicos no processo de hemocaterese e, em bem menor proporção pelas células de Kupffer. A bilirrubina indireta é conjugada no hepatócito com radicais glicurônicos (por ação da UDP-glicuroniltransferase) formando a bilirrubina direta (hidrossolúvel) e sob esta forma é excretada pela bile. Os sais biliares têm um importante papel na emulsificação de lipídios no intestino, possibilitando a sua digestão por lipase-colipase pancreática e conseqüente absorção pelos enterócitos. Os ácidos cólicos e quenodesoxicólico são considerados ácidos biliares primários porque são sintetizados pelo próprio hepatócito, tendo o colesterol como precursor. Nesse processo, o ácido cólico é conjugado com os aminoácidos taurina e glicina, resultando em ácido glicocólico ou taurocólico, respectivamente. Já os ácidos desoxicólico e litocólico são ácidos biliares secundários sendo sintetizados por bactérias do lúmen intestinal. Em verdade, somente $10 \%$ dos ácidos biliares são sintetizados pelo hepatócito, os $90 \%$ restantes são absorvidos pelo intestino delgado e chegam ao fígado, mais especificamente ao hepatócito, pela circulação sanguínea e são reexcretados pelo processo conhecido como recirculação entero-hepática.

A bile produzida pelos hepatócitos é liberada nos canalículos biliares. O canalículo biliar é um canal extracelular (com um diâmetro bem reduzido de 0.5-1.5 $\mu \mathrm{m}$ ), cuja parede é constituída pela superfícies apicais, contendo microvilos, de dois hepatócitos adjacentes unidos por junções de oclusão (Figura 14.3). 3,4 Essas junções, por permitirem uma firme interação das membranas, praticamente obliteram o espaço intercelular, formando uma barreira (a barreira hematobiliar) que isola o lúmem do canalículo e evita o extravasamento da bile.

Os canalículos biliares se anastomosam à medida que percorrem a placa de hepatócitos e confluem para a periferia do lóbulo; nesse local, continuam com o dúctulo biliar, também denominado canal de Hering (Figura 14.3), conduto de curto trajeto cuja luz é delimitada, em parte, pelos hepatócitos e, em parte, por células epiteliais denominadas colangiócitos. ${ }^{8}$ Estes dúctulos, inicialmente, apresentam colangiócitos cuboides, contendo, no seu citoplasma, discretos retículo endoplasmático e cisternas do Golgi. 
Dos canais de Hering, a bile é drenada para os ductos intralobulares dos espaços portais. ${ }^{8}$ Ductos menores são revestidos por um epitélio simples cúbico que passa a ser simples cilíndrico nas vias biliares de maior calibre. Os colangiócitos cilíndricos apresentam considerável aumento de retículo endoplasmático e do complexo de Golgi. Ductos de maior calibre também são envolvidos por fibras musculares lisas esparsas e, mais externamente, por tecido conjuntivo. Nesse tecido conjuntivo, pode-se verificar uma rede capilar própria, denominada plexo vascular peribiliar, originário de ramos terminais da artéria hepática. Essas diferenças morfológicas estão diretamente associadas às distintas funções que os colangiócitos exercem ao longo da árvore biliar, como processos secretórios e absortivos.

Embora os hepatócitos adicionem os elementos principais da bile, são os colangiócitos que ajustam o seu conteúdo e sua alcalinidade para que ela desempenhe seu papel. ${ }^{8}$ Para tanto, a atividade dessas células é controlada por uma complexa integração de fatores neuroendócrinos, parácrinos e autócrinos.Por exemplo, a secreção de bicarbonato é induzida por secretina, bombesina, glucagon e polipeptídeo vasoativo intestinal e inibida por somatostatina, insulina e gastrina. Além de regular a alcalinidade, os colangiócitos são capazes de reabsorver componentes da bile como sais biliares, glicose e glutationa.

Quadro 14.1 - Regeneração e proliferação hepática

A velocidade de renovação dos hepatócitos no indivíduo adulto e saudável é bastante lenta; a vida média do hepatócito é de 200 a 300 dias; contudo, a capacidade regenerativa do fígado adulto é bastante ampla e reflete uma complexa resposta fisiológica à ressecção cirúrgica ou injúria hepática, onde a porção do órgão remanescente inicia uma série de reações que promovem a replicação celular ou o crescimento para restaurar as funções hepáticas, onde a replicação celular é mediada por fatores endócrinos, parácrinos e autócrinos. Assim, o fígado pode ser restaurado a partir de células maduras preexistentes, que constitue a primeira opção de resposta ao dano hepático. ${ }^{9}$ Também mostra, entretanto, células progenitoras como um compartimento de reserva que é ativado quando a capacidade regenerativa das células maduras está comprometida. ${ }^{910}$

A origem das células progenitoras hepáticas é muito investigada e discutida, dado o interesse do tema para estabelecimento de terapias para 0 tratamento e controle de doenças crônicas hepáticas e para maior sucesso nos casos de transplante.,10 Atualmente, parece já estar bem estabelecido que essas células se originam de nichos de células progenitoras no trato biliar, particularmente nos canais de Hering, sendo que estas células têm potencialidade tanto para originar hepatócitos como colangiócitos. Essa população de células progenitoras parenquimais é representada por células pequenas, quando comparadas com os hepatócitos preexistentes, de núcleo ovoide e citoplasma escasso e que por conta dessa morfologia foram denominadas células ovais. As células ovais respondem a uma série de eventos de sinalização, em momentos distintos, sendo que as respostas a estes fatores podem ser agrupadas em quatro estágios: ativação, proliferação, migração e diferenciação. 
Dada a associação das células ovais aos processos de injúria hepática, tem sido postulado que alterações na frequência ou capacidade proliferativa destas células podem contribuir para 0 câncer hepático. ${ }^{9,10}$ De fato, a identificação de uma série de oncogenes (c-myc, Ras) e da expressão de proteínas fetais (como a proteína alfa-feto, proteína usualmente expressa por células tumorais) nas células ovais ativadas tem contribuído para essa hipótese. Finalmente, outro aspecto que tem estimulado pesquisas na área é a estreita relação entre o fígado e o pâncreas durante o desenvolvimento embrionário. Estudos investigam a possibilidade de existir uma célula precursora hepatopancreática (célula fonte ou stem cell) que possa persistir no fígado e no pâncreas do indivíduo adulto. ${ }^{9,10}$ Esta hipótese tem sido fortalecida a partir de ensaios onde células semelhantes a hepatócitos surgem no pâncreas de roedores em resposta a numerosos estímulos, como carcinógenos, por exemplo. Em humanos, a existência dessa célula progenitora comum tem sido sugerida pela expressão de marcadores hepatocelulares em câncer de pâncreas. Por outro lado, também ocorrem células progenitoras no fígado que expressam marcadores pancreáticos, como células de colangiocarcinomas que expressam amilase e lipase do tipo pancreática. Observou-se ainda que células ovais em cultura secretam insulina e ao serem transplantadas em ratos diabéticos restauram a função pancreática. No entanto, apesar das várias hipóteses apresentadas, o completo esclarecimento da origem da célula precursora hepática ainda está por vir a partir de estudos in vitro, in vivo e clínicos que vem sendo desenvolvidos de forma crescente.

\subsection{HISTOLOGIA DAS VIAS BILIARES EXTRA-HEPÁTICAS}

Os ductos biliares extralobulares confluem, formando ductos progressivamente maiores até drenarem um lobo hepático. Os ductos hepáticos direito e esquerdo coletam, respectivamente, a bile de todos os segmentos hepáticos da parte direita ou esquerda do fígado e no hilo se unem para formar o ducto hepático comum (Figura 14.1).

O ducto hepático comum se une ao ducto cístico (ducto da vesícula biliar) para formar o ducto colédoco (ou ducto biliar comum) (Figura 14.1). Frequentemente, o ducto pancreático desemboca no ducto colédoco, formando a ampola hepatopancreática, cuja extremidade distal estreitada se abre na papila duodenal maior (papila de Vater). Podem ocorrer, entretanto, variações anatômicas na desembocadura desses ductos no duodeno.

Os ductos biliares extra-hepáticos são revestidos internamente por um epitélio simples cilíndrico apoiado em uma lâmina própria de tecido conjuntivo com fibras musculares lisas esparsas, exceto nas regiões inferiores de desembocadura dos ductos colédoco e pancreático na ampola hepatopancreática e ao redor dela. ${ }^{3,4}$ Nessa região, as células musculares lisas se organizam circularmente, formando esfíncteres. $\mathrm{O}$ ducto colédoco e o ducto pancreático apresentam esfíncteres próprios. Ao redor da ampola hepatopancreática, ocorre um espessamento dessa camada muscular, formando o esfíncter da ampola hepatopancreática, ou 
esfíncter de Oddi. A lâmina própria do ducto colédoco apresenta grupos de glândulas túbulo-alveolares secretoras de muco.

\subsection{HISTOLOGIA DA VESÍCULA BILIAR}

Do ponto de vista histológico, a parede da vesícula biliar é composta por três túnicas, mucosa, muscular e de tecido conjuntivo externa, que pode ser serosa ou adventícia, dependendo da face da vesícula biliar em questão (Figura 14.8). ${ }^{3,4} \mathrm{~A}$ face do órgão voltada para o fígado é recoberta por uma túnica adventícia, mas a face oposta a ele é revestida por uma túnica serosa.

A mucosa da vesícula biliar apresenta muitas pregas, especialmente se o órgão está vazio. O epitélio que reveste a sua luz é simples cilíndrico e suas células colunares altas apresentam citoplasma levemente acidófilo, em razão de mitocôndrias (Figura 14.8). O pólo apical dessas células apresenta curtas microvilosidades e nos domínios laterais da membrana plasmática, junções de oclusão bem desenvolvidas. O núcleo oval tem localização basal. A lâmina própria de tecido conjuntivo apresenta glândulas mucosas, especialmente na região do colo. Nessa região do colo, a túnica mucosa também possui pregas dispostas em espiral, formando a denominada válvula espiral, ou de Heister.

A vesícula biliar não apresenta muscular da mucosa, nem a túnica submucosa. Os feixes de fibras musculares lisas da túnica muscular são entremeados por fibras colágenas e elásticas (Figura 14.8).

A vesícula biliar tem a função de armazenar e concentrar a bile diluída proveniente dos ductos hepáticos em até 20 vezes. A concentração da bile ocorre por absorção de água e eletrólitos, como o $\mathrm{Na}^{+}$, pelas células epiteliais que revestem a sua luz. Pregas da mucosa e de microvilos no ápice da célula epitelial de revestimento aumentam a superfície de contato do epitélio com a bile, favorecendo os transportes que ocorrem transcelularmente. Ainda, as junções de oclusão, formando um cinturão ao redor das células epiteliais, evitam o extravasamento de componentes da bile, permitindo a passagem apenas de moléculas de água a favor do gradiente osmótico. Durante o período de jejum, o esfíncter da ampola hepatopancreática está fechado. Assim, a bile produzida é drenada para a vesícula biliar através do ducto cístico. Após uma refeição, os lipídios na luz intestinal desencadeiam a contração da musculatura da parede da vesícula biliar e o relaxamento do esfíncter da ampola hepatopancreática em resposta à colecistocinina. 

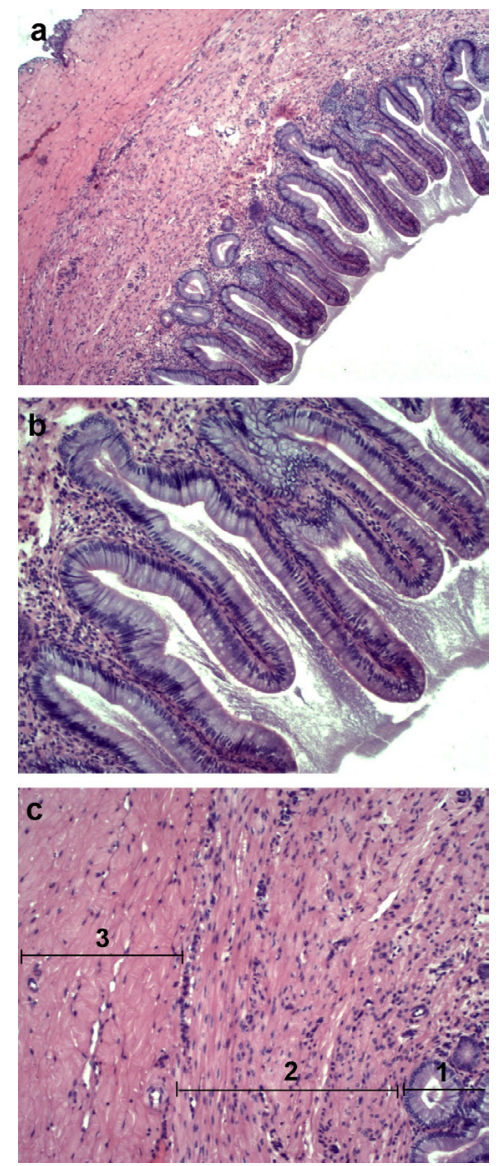

Figura 14.8 - Fotomicrografia de corte histológico de vesícula biliar em aumento panorâmico (a) e em médio aumento $(b, c)$ mostrando as túnicas mucosa (b, e 1 em c), muscular $(2$ em c) e adventicia (3 em c) que compõem a parede do órgão.

\subsection{HISTOLOGIA DO PÂNCREAS}

O pâncreas é a segunda maior glândula associada ao tubo digestivo. Ele é envolvido por uma cápsula muito delgada de tecido conjuntivo de onde partem septos que subdividem a glândula em lóbulos. Os septos de tecido conjuntivo contêm vasos sanguíneos, vasos linfáticos, nervos e ductos excretores. A irrigação do pâncreas é feita por vasos derivados da artéria celíaca, da artéria mesentérica superior e da artéria esplênica. A drenagem venosa flui para a veia esplênica e sistema porta. A inervação aferente é feita pelos nervos esplênico e vago.

O parênquima do pâncreas consiste de: 1) uma porção exócrina que compõe cerca de $98 \%$ de todo o parênquima e secreta diariamente $1200 \mathrm{ml}$ de um fluido alcalino 
rico em enzimas necessárias para a digestão de amido, gorduras e proteínas; e 2) uma porção endócrina, que perfaz aproximadamente $2 \%$, secreta cinco hormônios cujas ações estão direta e indiretamente relacionadas à homeostasia glicêmica.

\subsection{PÂNCREAS EXÓCRINO: ORGANIZAÇÃO TECIDUAL, CITOLOGIA E ULTRAESTRUTURA}

O pâncreas exócrino é classificado morfologicamente como uma glândula acinosa composta, ou seja, é constituído por várias unidades secretoras arranjadas na forma de ácinos que desembocam num sistema ramificado de ductos (Figura 14.9a). ${ }^{3,4}$ Os ácinos são do tipo seroso (secretor de proteínas) e, na luz deles, inicia-se o sistema de ductos secretor-excretores e também se encontram as células centroacinares, células exclusivas do pâncreas (Figura $14.9 \mathrm{~b}$, setas). As células centroacinares são contínuas com o epitélio simples cúbico baixo que reveste o ducto intercalar (Figura 14.9c). Os ductos intercalares convergem para formar os ductos interlobulares, estes revestidos por um epitélio simples cilíndrico com algumas células caliciformes e neuroendócrinas, e imersos no tecido conjuntivo do septo (Figura 14.9d). Os ductos interlobulares se anastomosam para formar o ducto pancreático principal (ou ducto de Wirsung), que apresenta uma estrutura histológica semelhante aos ductos interlobulares. $\mathrm{O}$ ducto pancreático principal tem um percurso retilíneo por meio da cauda e do corpo, coletando secreções dos ductos interlobulares e tornando-se mais calibroso à medida que se aproxima da cabeça (Figura 14.1). Quando atinge a cabeça do pâncreas, desemboca diretamente no duodeno, na ampola de Vater, após se unir ao ducto colédoco (ou ducto biliar comum).

O ácino seroso constitui a unidade histológica funcional do pâncreas exócrino (Figura 14.10a).,3 $\mathrm{O}$ ácino (palavra derivada do grego que quer dizer "bago de uva") tem um formato arredondado composto por 40 a 50 células, as células acinares pancreáticas, organizadas ao redor de um lúmen de tamanho bem reduzido. As células acinares têm um formato trapezoide ou piramidal, cuja base é mais larga do que o ápice, o que facilita a organização tridimensional do ácino (Figura 14.10b). Essas células apresentam uma polaridade bem evidente, representada por uma distribuição assimétrica de organelas no citoplasma. Estas células estão firmemente unidas umas às outras por junções intercelulares (principalmente junções de oclusão e desmossomos) localizadas na porção superior da membrana lateral, que impedem o refluxo para o espaço intercelular dos produtos secretados no lúmen do ácino.

Em cortes histológicos, o citoplasma próximo à região basal da célula acinar é fortemente basófilo em virtude da grande concentração de retículo endoplasmático rugoso e polirribossomos (ricos em ácido ribonucléico) (Figura 14.10a). Essas organelas perfazem quase $20 \%$ do total do volume celular e são fundamentais na síntese 
dos produtos de secreção desta célula. O núcleo esférico da célula acinar tem localização basal ou para-basal e contém um nucléolo proeminente e agregados de heterocromatina na periferia (Figura 14.10a, b). Na região supranuclear, há uma região menos corada onde se concentra o complexo de Golgi. A região apical é altamente acidófila e repleta de vesículas secretoras, que em razão da sua aparência à microscopia eletrônica de transmissão, são denominadas grânulos de secreção ou grânulos de zimogênio (que contém pró-enzimas) (Figura 14.10c).

A função principal das células acinares pancreáticas é sintetizar, estocar e secretar 20 enzimas digestivas, como alfa-amilase, lipase-colipase e proteases, que catalizarão a hidrólise de amido, lipídios e proteínas, respectivamente, ingeridos nas refeições. A maioria das enzimas pancreáticas é armazenada na forma inativa (pró-enzimas), o que inclui todas as proteases, as quais são ativadas, em condições fisiológicas, somente no lúmen do duodeno sob a ação de enzimas intestinais e em $\mathrm{pH}$ ligeiramente alcalino. Este é um fato importante para a proteção do pâncreas contra a ação destas enzimas.

A síntese das enzimas pancreáticas inicia-se, à semelhança de qualquer outra proteína, com a transcrição do DNA em RNAm, o qual é convertido em uma sequência de aminoácidos nos ribossomos associados ao retículo endoplasmático no citoplasma da célula acinar. A molécula proteica completa é transferida para o complexo de Golgi e empacotada dentro de vesículas secretoras. Após um processo de maturação, que envolve perda de água, formam-se os grânulos de zimogênio, que se concentram na porção apical da célula.

A secreção acinar pancreática é primariamente induzida pela ingestão de alimento, a qual desencadeia múltiplas vias de regulação neuroendócrina e parácrina que modulam a liberação de quantidades adequadas de enzimas no lúmen duodenal. ${ }^{11}$ Dentre os vários moduladores da secreção enzimática pancreática, destacam-se: 1) a colecistocinina, secretada pelas células enteroendócrinas da mucosa intestinal, estimuladas por produtos de digestão de proteínas e lipídios, e 2) a acetilcolina, liberada pela inervação parassimpática. ${ }^{11}$ Ambos agonistas interagem com receptores localizados na membrana basal da célula acinar e desencadeiam a via de sinalização intracelular mediada pelo IP3/diacilglicerol, resultando em um aumento da concentração de cálcio citoplasmático, especificamente no pólo apical da célula (onde ficam localizados os grânulos de zimogênio). O íon cálcio e a reorganização da rede microfilamentos de actina são essenciais para promover o transporte dos grânulos para as proximidades da membrana apical. Numa etapa seguinte, ocorre a fusão da membrana do grânulo com a membrana apical, que depende de proteínas de ancoragem de membranas pertencentes à familia das

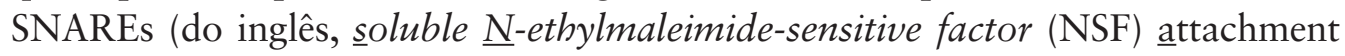


receptors, receptores de ancoragem do fator sensível ao N-etilmaleimida), e consequente exocitose dos grânulos, liberando o seu conteúdo no lúmen do ducto. ${ }^{12}$

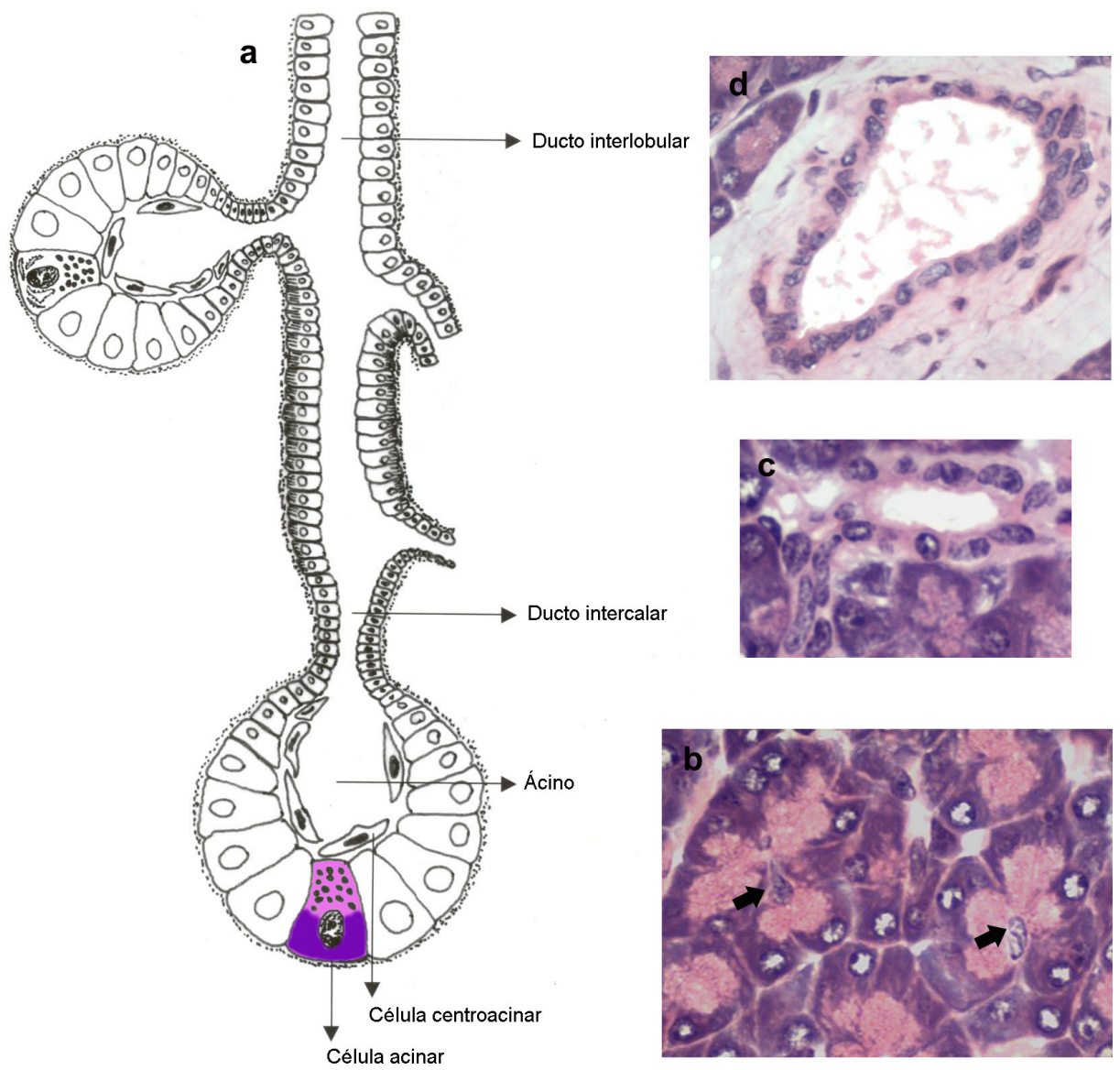

Figura 14.9 - Esquema (a) e fotomicrografias da estrutura histológica do pâncreas que é composta por uma porção secretora em forma de ácino (b) e um sistema de ductos ramificados: ducto intercalar (c) e ducto interlobular (d). Setas em b indicam células centroacinares. Esquema modificado de Taboga et al. (2005) In: Carvalho, H. F. \& Collares-Buzato, C. B. Células: uma abordagem multidisciplinar. Editora Manole, SP, pp. 156-162. 

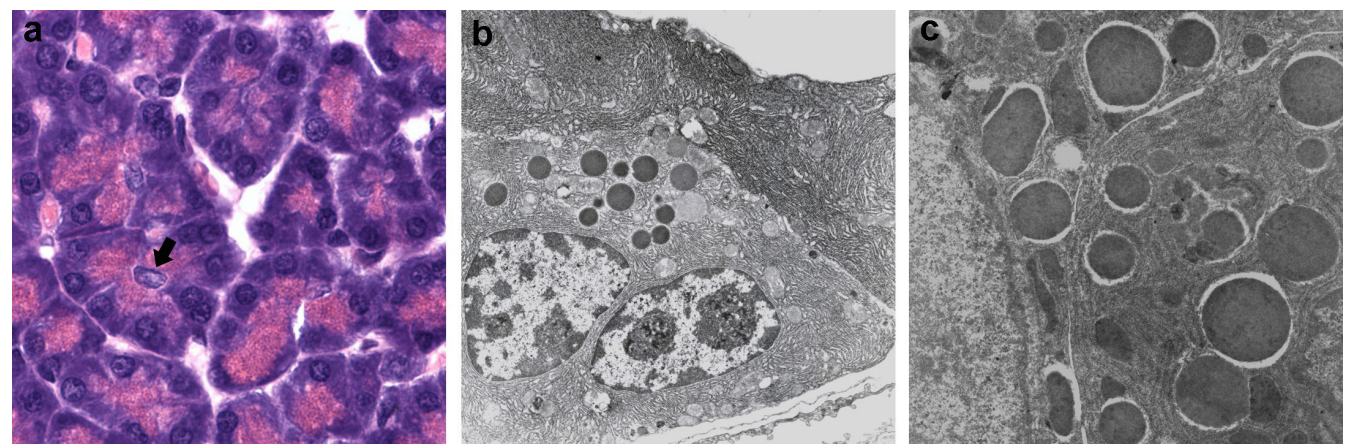

Figura 14.10 - Citologia e ultraestrutura da célula acinar pancreática. Em a, detalhe de um corte histológico de um ácino seroso (corado com hematoxilina e eosina e observado por microscopia de luz), o qual é formado pelas células acinares pancreáticas. No lúmen do ácino, observa-se o núcleo da célula centroacinar (seta). Em b, fotomicrografia ultraestrutural da célula acinar pancreática e de seus componentes, incluindo os grânulos de zimogênio (detalhe em c). Imagem b, cortesia de Paulo P Joazeiro.

Várias dessas etapas de secreção estão alteradas na pancreatite, aguda ou crônica, indicando um papel central da célula acinar pancreática na etiologia dessa doença. Os principais eventos intracelulares desencadeadores da pancreatite parecem ser: 1) o bloqueio do processo normal de exocitose apical dos grânulos; 2) a indução da exocitose basolateral dos grânulos, provavelmente resultante de alterações na localização e expressão de proteínas SNAREs, responsáveis pela ancoragem dos grânulos na membrana plasmática; 3) o aumento generalizado da concentração citoplasmática de $\mathrm{Ca}^{+2}$, inclusive no pólo basolateral da célula; e 4) a fusão de lisossomos e grânulos de zimogênio, levando à ativação citoplasmática das pró-enzimas por enzimas lisossomais. ${ }^{2,12,13} \mathrm{O}$ processo de injúria e morte da célula acinar pancreática é propagado e amplificado por eventos extracelulares, que incluem uma insuficiência da microcirculação sanguínea local, o desencadeamento de um processo inflamatório mediado por citocinas, culminando em necrose e posterior fibrose do pâncreas.

O suco pancreático, além das enzimas e pró-enzimas, contém grande quantidade de água e eletrólitos, dentre os quais os mais abundantes são o $\mathrm{Na}^{+}$e o $\mathrm{HCO}_{3}$. Este componente aquoso do suco pancreático, que é alcalino e isotônico em relação ao fluido extracelular, é secretado pelas células centroacinares e as ductais e tem a função de neutralizar a acidez do quimo, evitando possível lesão da mucosa intestinal e permitindo a ativação das enzimas pancreáticas no lúmen do duodeno. 
As células ductais, que revestem a porção excretora do pâncreas, têm um formato poliédrico (que varia de cúbico a cilíndrico dependendo do calibre do ducto), com um citoplasma ligeiramente acidófilo e um núcleo grande e indentado (Figura 14.9d). À microscopia eletrônica de transmissão, essa célula é caracterizada por apresentar poucas mitocôndrias, bem como retículo endoplasmático rugoso e complexo de Golgi relativamente pouco desenvolvidos em comparação com os da célula acinar. As células centroacinares, que se inserem no lúmen do ácino, assemelham-se ultraestruturalmente às células ductais, embora apresentem um formato mais alongado e um núcleo elíptico (o qual permite a identificação deste tipo celular em preparados histológicos do pâncreas, já que seu limite celular não é visível) (Figura 14.9b e 14.10a). Tanto as células centroacinares como as ductais apresentam transportadores e canais em suas membranas plasmáticas responsáveis pelo transporte ativo de eletrólitos (principalmente $\mathrm{Na}^{+}, \mathrm{HCO}_{3}^{-} \mathrm{e} \mathrm{Cl}^{-}$) entre o compartimento luminal e basolateral da célula. ${ }^{15}$

$\mathrm{O}_{\mathrm{HCO}_{3}}^{-}$do suco pancreático é derivado do plasma ou produzido dentro da célula centroacinar/ductal como resultado da dissociação de $\mathrm{CO}_{2}$ e $\mathrm{H}_{2} \mathrm{O}$ em $\mathrm{HCO}_{3}^{-}$e $\mathrm{H}^{+}$sob a ação da anidrase carbônica. ${ }^{15}$ A secreção de $\mathrm{HCO}_{3}^{-}$para o lúmen do ducto, por sua vez, envolve várias etapas, tais como: 1) o contratransporte de $\mathrm{Na}^{+}$(para dentro da célula) e $\mathrm{H}^{+}$(para fora) na membrana basal; 2) o contratransporte de $\mathrm{HCO}_{3}^{-}$(para fora no lúmen) e $\mathrm{Cl}^{-}$(para dentro da célula) na membrana apical da célula centroacinar/ductal e 3) a secreção de $\mathrm{Cl}^{-}$para o lúmen, mediado pelo canal de $\mathrm{Cl}^{-}$localizado na membrana apical, que mantém uma concentração luminal deste íon adequada para o contratransporte com o $\mathrm{HCO}_{3}$ $\mathrm{O} \mathrm{Na}^{+}$move-se a favor do gradiente eletroquímico, do plasma para o lúmen pela via paracelular, estabelecendo um gradiente osmótico que resulta também em transporte luminal de $\mathrm{H}_{2} \mathrm{O}$.

A secreção do componente aquoso do suco pancreático, à semelhança do conteúdo enzimático, está sob a regulação neuroendócrina, sendo a secretina o principal secretagogo. A secretina é liberada pelas células enteroendócrinas do intestino delgado sob o estímulo da acidez do quimo. Este hormônio interage com receptores na membrana basal das células centroacinares e ductais e, via proteína cinase dependente de $\mathrm{AMPc}$ (PKA), ativa o canal apical de $\mathrm{Cl}^{-}$e, consequentemente, estimula a secreção luminal de $\mathrm{Cl}^{-}$e de $\mathrm{HCO}_{3} \cdot{ }^{-15} \mathrm{O}$ resultado final é a secreção de um grande volume de fluido rico em $\mathrm{HCO}_{3}$. Um defeito genético na proteína do canal de $\mathrm{Cl}$, chamada de regulador transmembranar de condutância da fibrose cística (CFTR), é responsável pela fibrose cística. ${ }^{4,15}$ No pâncreas, a ausência de secreção de $\mathrm{Cl}^{-}$ resultante dessa doença genética leva à secreção pancreática espessa e viscosa que obstrui os ductos pancreáticos, formando cistos envolvidos por extensa fibrose. 
Outra enfermidade associada ao pâncreas exócrino é o carcinoma pancreático, uma das neoplasias malignas mais agressivas, cuja origem celular ainda não está totalmente definida, mas possivelmente as células centroacinares e as ductais configuram-se como as principais candidatas (Quadro 14.2).

Todas essas doenças que afetam o pâncreas (como o câncer, a pancreatite e a fibrose cística) estão associadas com extensa fibrose do parênquima pancreático. Recentemente, foi demonstrado que, à semelhança do que acontece no fígado, a fibrose pancreática é também resultante da ativação de células estreladas, que são encontradas em pequena quantidade na região periacinar. ${ }^{16}$ Esse achado reforça ainda mais as similaridades histopatológicas entre esses dois órgãos, que compartilham uma origem embriológica comum.

Quadro 14.2 - Em busca das origens celulares do câncer pancreático.

0 adenocarcinoma ductal pancreático (ADP) é um cancer particularmente agressivo e letal. É desconhecido se o ADP é derivado da dediferenciação de células ductais, de células acinares ou de células endócrinas pancreáticas ou, ainda, resultado de diferenciação imperfeita de uma célula precursora ou fonte (talvez com uma origem hepatopancreática comum) que persiste no pâncreas adulto. ${ }^{17} 0$ aspecto histológico desse tumor sugere uma origem ductal, entretanto, a observação de uma metaplasia acinoductal, que frequentemente precede $0 \mathrm{ADP}$, sugere uma origem acinar. Alguns investigadores têm proposto que $0 \mathrm{ADP}$ derive de células endócrinas pancreáticas, das raras células precursoras ou ainda da transdiferenciação de células beta. Mais recentemente, estudos sugerem que 0 câncer pancreático teria origem da dediferenciação das células centroacinares. A observação de que as células centroacinares apresentam a via de sinalização Notch ativa (importante via durante a organogênese e que mantém as células progenitoras em estado indiferenciado), aliado ao fato de sua localização estratégica (na interface entre a estrutura acinar e 0 sistema ductal) coloca este tipo celular como candidato potencial relacionado à origem do $\mathrm{ADP}$.

\subsubsection{PÂNCREAS ENDÓCRINO: ORGANIZAÇÃO TECIDUAL, CITOLOGIA E ULTRAESTRUTURA}

Imersas no tecido pancreático exócrino, estão as ilhotas pancreáticas, ou ilhotas de Langerhans, que, sob microscopia de luz, apresentam-se na forma de aglomerados arredondados (ou ovalados) de células endócrinas, que aparecem palidamente coradas com corantes empregados rotineiramente, em cortes histológicos da glândula (Figura 14.11a). ${ }^{3,4} \mathrm{O}$ conjunto de ilhotas pancreáticas forma o pâncreas endócrino. As ilhotas são envolvidas por uma delgada cápsula (pouco evidente em preparados histológicos da glândula), rica em fibras reticulares e que as separa do parênquima exócrino. As ilhotas estão distribuídas aleatoriamente pelo pâncreas, embora haja uma concentração maior de ilhotas na região da 
cauda em relação ao corpo e cabeça da glândula. Estima-se um número aproximado de um milhão de ilhotas no pâncreas humano, que perfazem apenas 1-2\% do volume total da glândula. Cada ilhota contém aproximadamente de duas a três mil células dispostas em cordões ou placas entremeadas por uma rica rede de capilares sanguíneos fenestrados.
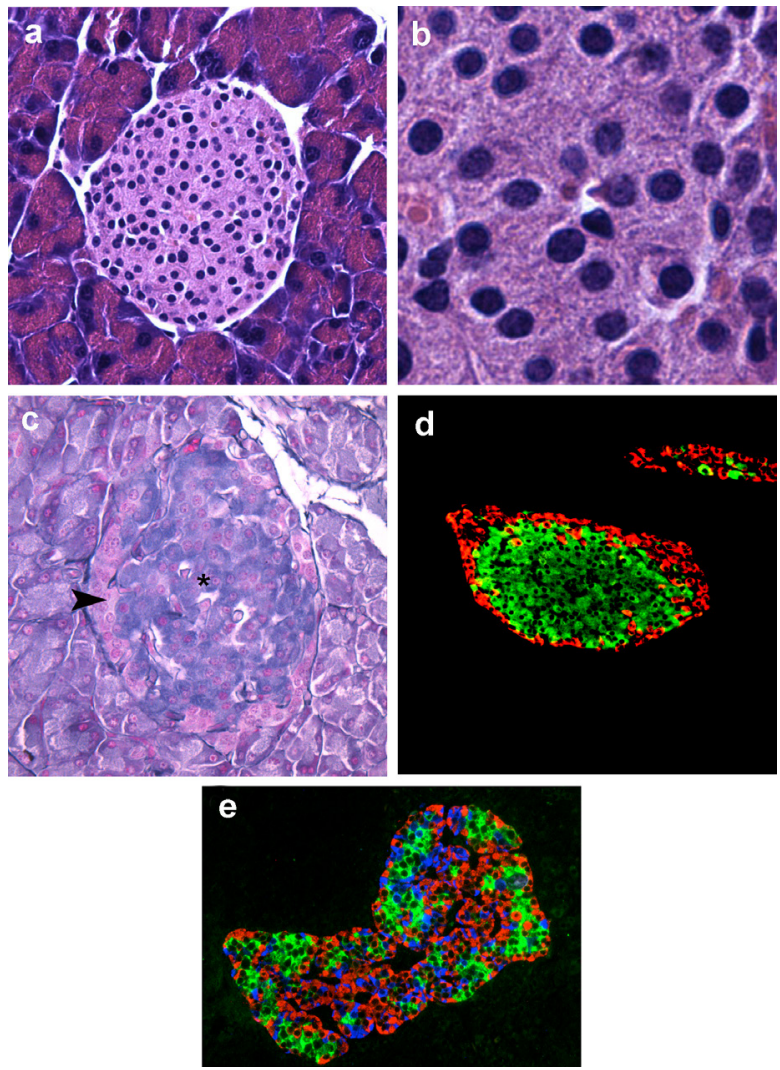

Figura 14.11 - Fotomicrografias de cortes histológicos de ilhotas pancreáticas murinas (a-d) e humana (e). Em a e b, ilhotas coradas com Hematoxilina e Eosina; $a$, em aumento médio e b, em grande aumento mostrando detalhe da morfologia das células endócrinas pancreáticas. Em c, ilhota corada com hematoxilina crômica-floxina, que permite a distinção de células beta (em azul, ocupando a regiáo central da ilhota, asterisco) das não beta (em rosa, localizadas na periferia da ilhota, cabeça de seta). Em de e, ilhotas processadas para imuno-histoquímica para insulina (verde), glucagon (vermeIho) e somatostatina (azul; em e). Imagem reproduzida do periódico PLoS ONE 6(11): e27445, 2011. doi:10.1371/journal. pone.0027445 (autores: Kilimnik $\mathrm{G}$ et al.), sob licença da Creative Commons.

As ilhotas são constituídas por cinco tipos celulares com função endócrina, cada uma responsável em secretar um hormônio peptídico distinto: as células beta, secretoras de insulina; as células alfa, secretoras de glucagon; as células 
delta, secretoras de somatostatina; as células PP ou F, que secretam o polipeptídeo pancreático; e as células épsilon, produtoras de grelina. ${ }^{3,4,18}$

Esses hormônios estão direta ou indiretamente envolvidos na homeostase glicêmica: a insulina tem ação hipoglicemiante, enquanto o glucagon tem ação hiperglicemiante; a somatostatina possui uma ação inibitória sobre várias funções gastrointestinais, que resultam em diminuição na absorção intestinal de nutrientes, e também sobre a secreção de insulina e glucagon; o polipeptídeo pancreático pode exercer um papel inibitório na secreção exócrina pancreática, e grelina tem uma ação, primariamente, parácrina, inibindo a secreção de insulina. O comprometimento do balanço da secreção destes hormônios pode resultar em disfunções tal como a diabetes melito, doença potencialmente fatal envolvendo uma secreção insuficiente ou ausente de insulina pelas células beta.

Embora funcionalmente diferentes, as células endócrinas da ilhota apresentam características citológicas muito semelhantes entre si, dificultando a sua identificação em preparados histológicos do pâncreas endócrino. Essas células apresentam um formato poliédrico com um citoplasma ligeiramente acidófilo e um núcleo arredondado ou elíptico de localização central, que pode conter de um a dois nucléolos evidentes no seu interior (Figura 14.11a e b). Para a distinção, ao microscópio de luz ou fotônico, destes tipos celulares da ilhota, é necessário a utilização de métodos histoquímicos ou imuno-histoquímicos seletivos para determinado tipo celular (Figura 14.11c-e).

A proporção e distribuição dos tipos celulares são diferentes nas ilhotas pancreáticas. No caso de ilhotas de roedores, as proporções aproximadas de cada tipo celular em relação ao volume total da ilhota são: 70-80\% de células beta, $15-20 \%$ de células alfa, $5 \%$ de células delta e menos de 1\% de células PP e épsilon. Estudos com ilhotas humanas mostraram que esta proporção é diferente da encontrada em roedores, de tal forma que a ilhota humana é constituída por aproximadamente $55 \%$ de células beta, cerca de $35 \%$ de células alfa, $6 \%$ de células delta e o restante por células PP e épsilon. ${ }^{18}$

Quanto à organização destes tipos celulares, sabe-se que, em roedores, as células beta localizam-se na região central da ilhota, enquanto as células não beta se organizam na periferia, envolvendo as células beta (Figura 14.11c e d). As ilhotas humanas também mostram esta citoarquitetura, embora menos definida do que em roedores. As células endócrinas das ilhotas humanas estão, de fato, organizadas em placas epiteliais trilaminares e anatomosantes que são entremeadas por capilares. ${ }^{18}$ Nas placas epiteliais, a maioria das células beta está localizada na região central ladeada por células não beta (Figura 14.11e). Em relação àquela apresentada pelas ilhotas de roedores, essa citoarquitetura das ilhotas humanas, favorece os contatos heterotípicos entre as células beta e células alfa, cujo significado funcional ainda não é conhecido. ${ }^{18}$ 
Alterações tanto na proporção numérica dos tipos celulares bem como na sua organização espacial (citoarquitetura) das ilhotas são verificadas em animais com quadro estabelecido de diabetes ou em modelos in vitro de disfunção secretora de insulina. Essas observações indicam um papel importante da organização tecidual do pâncreas endócrino na função deste órgão. ${ }^{19}$

Em cada ilhota, as células endócrinas se conectam, homotipica ou heterotipicamente, por meio das junções intercelulares do tipo comunicante, aderente, oclusão e desmossomos, como demonstrado por microscopia eletrônica de transmissão e imuno-histoquímica (Figura 14.12). Tais contatos intercelulares parecem ser cruciais para o perfeito funcionamento deste órgão. ${ }^{20} \mathrm{~A}$ expressão diferencial de subtipos de moléculas de adesão associadas à junção aderente determina a citoarquitetura da ilhota. A junção comunicante parece ser particularmente importante na secreção de insulina pelas células beta. Os canais intercelulares das junções comunicantes formados por conexinas atuam "transmitindo", de uma célula beta a outra, o aumento citossólico de $\mathrm{Ca}^{+2}$, desencadeado pelo metabolismo intracelular da glicose, e crucial para o processo de exocitose dos grânulos de insulina (Figura 14.12). A comunicação intercelular via junções comunicantes permite a otimização do processo de secreção de insulina de duas maneiras: 1) recrutando células beta acopladas e localizadas distantes do estímulo e, 2) diminuindo e/ou corrigindo a heterogeneidade funcional das células beta, que podem diferir com relação à biossíntese e resposta secretória de insulina a secretagogos, permitindo que subpopulações de células beta tenham respostas funcionais semelhantes. ${ }^{20}$
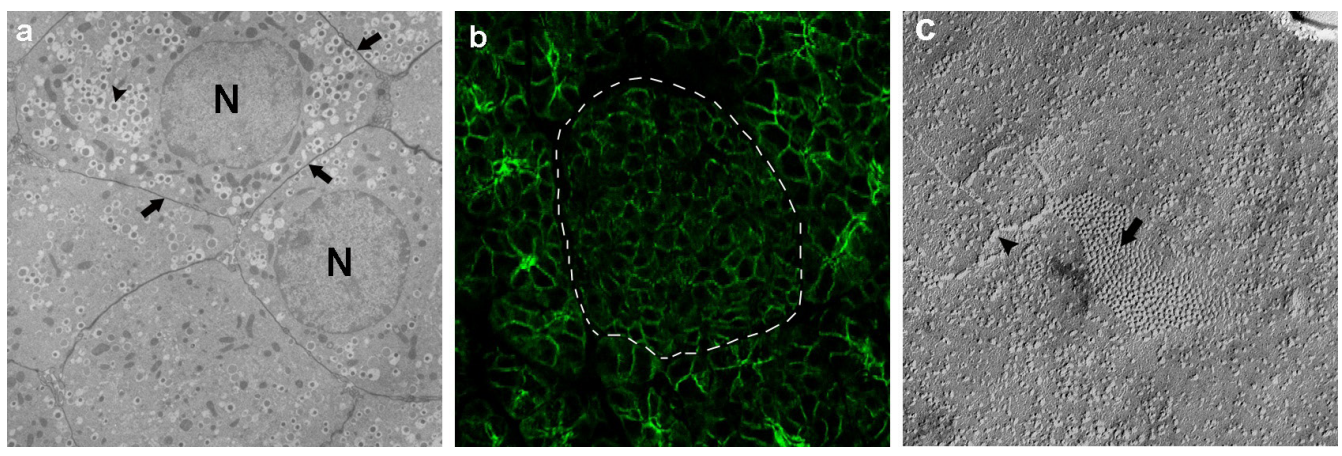

Figura 14.12 - Fotomicrografia ultraestrutural de uma célula beta justaposta a outra célula beta (pâncreas de rato) obtida por microscopia eletrônica de transmissão (a). Em a, setas indicam região de contato intercelular, cabeça de seta, grânulo de secreção e $\mathrm{N}$, núcleo. Na região de contato intercelular, essas células formam junções intercelulares que contêm proteínas de adesão, que podem ser detectadas por imunofluorescência (em verde, b). Em c, réplicas de criofraturas de membranas de uma célula beta contendo junções comunicantes (vistas como agregados de partí́culas, que correspondem aos canais intercelulares, seta) e junções de oclusão (constituídos por cordões de adesão, cabeça de seta). 
Ultraestruturalmente, as células endócrinas da ilhota apresentam características típicas de células epiteliais produtoras de hormônios de natureza protéica. ${ }^{3,4}$ Dentre essas caracteristicas, destacam-se um retículo endoplasmático rugoso e complexo de Golgi bem desenvolvidos (embora não sejam tão abundantes como os da célula acinar pancreática) e numerosos grânulos de secreção, eletrondensos, contendo o hormônio sintetizado (Figuras 14.12a e 14.13). Os aspectos ultraestruturais que permitem a distinção dos tipos celulares da ilhota por microscopia eletrônica de transmissão referem-se ao tamanho e a estrutura interna dos grânulos de secreção. ${ }^{3}$ Por exemplo, em humanos e outros mamíferos, as células beta têm grânulos de formato variável (de ovalado a poligonal) com a região central preenchida por uma estrutura cristaloide bastante eletrondensa, de formato irregular ou arredondada (contendo moléculas de insulina associadas com zinco), excêntrica e circundada por um halo claro amplo e com membrana vesicular (Figura 14.13a). Os grânulos das celulas alfa, contendo glucagon, são menores do que os da célula beta, dotados de um formato regular contendo um cerne arredondado e eletrondenso, cercado por um halo claro pequeno, sob a membrana do grânulo (Figura 14.13b). Os grânulos das células delta são maiores do que os dos outros tipos celulares da ilhota, e apresentam um formato bem regular, contendo um material pouco eletrondenso, preenchendo todo o espaço central do grânulo.
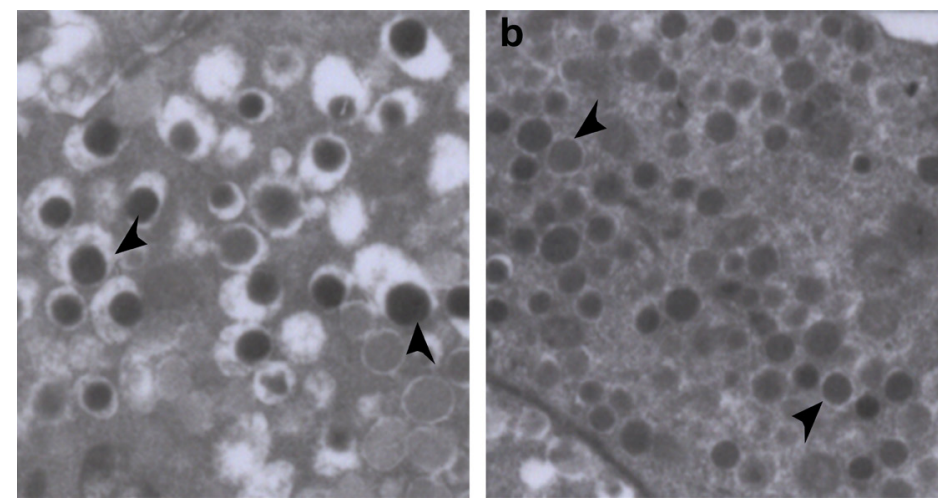

Figura 14.13 - Fotomicrografia ultraestrutural, mostrando as diferenças morfológicas dos grânulos de secreşão da célula beta, secretora de insulina (a) e da célula alfa, secretora de glucagon (b) (detalhes no texto). As cabeças de seta indicam os respectivos grânulos.

Os hormônios do pâncreas endócrino são polipeptídeos, portanto, sua síntese depende da maquinaria celular usual de síntese proteica. Os processos de síntese da insulina, pela célula beta, e do glucagon, pela célula alfa, está relativamente bem estabelecidos. A síntese inicia-se no retículo endoplasmático rugoso com a formação de um pré-pró-hormônio, que recebe a primeira clivagem ainda nesta 
organela, convertendo-se em pró-hormônio. A conversão do pró-hormônio em hormônio ocorre no complexo de Golgi e/ou no grânulo de secreção. As moléculas de hormônio ficam armazenadas nos grânulos, que, por sua vez, se acumulam próximo à superfície da membrana, situada nas proximidades de capilares. A liberação do hormônio ocorre por um processo de exocitose dos grânulos, que envolve aumento da concentração citoplasmática de $\mathrm{Ca}^{+2}$ e reorganização do citoesqueleto, sob o estímulo de um secretagogo.

O estímulo para a secreção hormonal na ilhota chega às células endócrinas principalmente pela circulação sanguínea. A irrigação sanguínea das ilhotas é bastante peculiar. Embora as ilhotas constituam parte muito pequena da massa total do pâncreas humano, o fluxo sanguíneo para o pâncreas ocorre predominantemente para ilhota e desta para o pâncreas exócrino; entretanto, arteríolas podem também desembocar diretamente em redes de capilares, irrigando os ácinos e ductos. As arteríolas aferentes se capilarizam nas ilhotas, formando uma rede de capilares fenestrados intimamente associados às células endócrinas. Esses capilares saem das ilhotas e levam sangue aos ácinos pancreáticos que cercam a ilhota, estabelecendo o sistema porta insuloacinar. ${ }^{21}$ Essa distribuição do fluxo sanguíneo no pâncreas é relevante para as ações fisiológicas, no contexto de local, dos hormônios do pâncreas endócrino. É bem conhecido o fato de que a insulina e a somatostatina tem uma ação estimulatória e inibitória, respectivamente, sobre a função secretora das células acinares. A importância do eixo insulinoacinar é particularmente evidente na diabetes melito, onde a deficiência de insulina resulta também em disfunção da célula acinar e fibrose do parênquima exócrino.

A diabetes melito é uma das doenças mais prevalentes associadas ao pâncreas endócrino. A deficiência na secreção de insulina associada a essa doença se decorre de uma destruição autoimune das células beta (diabetes tipo 1) ou à exaustão das células beta (levando à morte celular) desencadeada por um quadro de resistência periférica à insulina (diabetes tipo 2). Análise histológica do pâncreas de indivíduos diabéticos revela hialinização ou fibrose das ilhotas pancreáticas com destruição de grande parte das células betas (Figura 14.14). ${ }^{19}$ Grandes esforços são despendidos na tentativa de se achar uma forma eficiente de terapia celular desta doença (Quadro 14.3).

Tumores originados de células das ilhotas são relativamente raros; essas células tumorais podem produzir insulina, glucagon, somatostatina ou polipeptídeo pancreático ou uma combinação de dois ou mais hormônios simultaneamente, gerando sintomas clínicos complexos. 

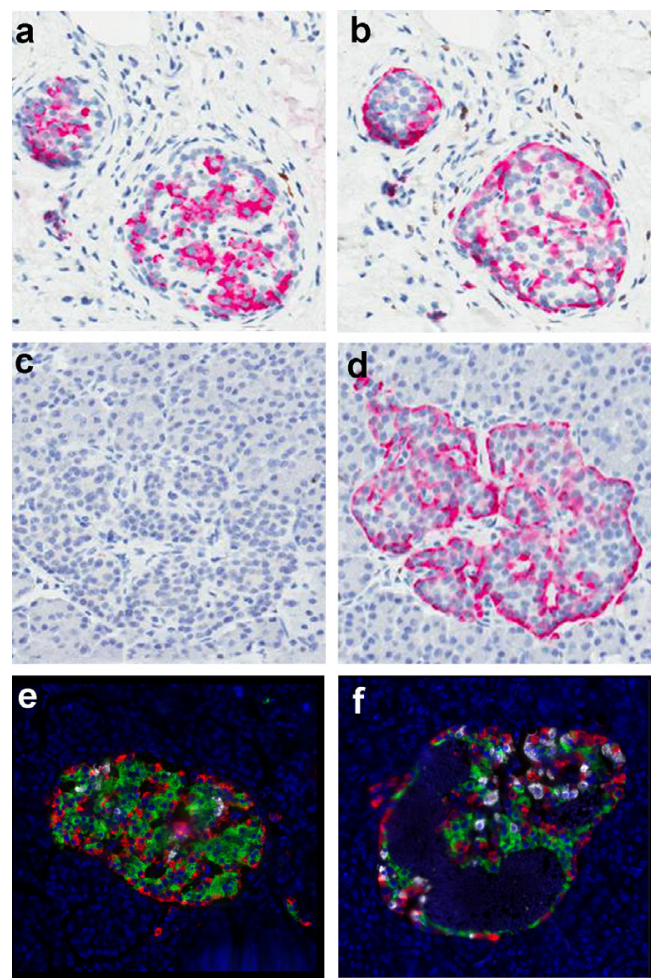

Figura 14.14 - Estrutura de ilhotas pancreáticas em indivíduos sadios (a, b, e) e diabéticos tipo 2 (c, d, f). № indivíduo sadio (a), as células beta (imunomarcadas para insulina, em rosa) ocupam grande parte do volume da ilhota (na região (entral), enquanto no diabético, há redução significativa do número de células beta ou mesmo perda total desse tipo celular na ilhota (c), enquanto as células alfa (imunomarcadas para glucagon, em rosa) são preservadas (d em relação a b). Ainda, ilhota de indivíduo diabético tipo 2 (f) mostra alterações morfológicas (como formação de cisto contendo material necrótico) e ruptura da citoarquitetura em relação à ilhota de não diabético (e). Em e e f, ilhotas processadas para imunoistoquímica para insulina (verde), glucagon (vermelho) e somatostatina (branco). Imagens a a d reproduzidas do periódico PLOS ONE 9(9): e106537, 2014. doi:10.1371/journal.pone.0106537 (autores: Subauste A et al.), sob licença da Creative Commons. Imagens e e f reproduzidas do periódico PLOS ONE 6(11): e27445, 2011. doi:10.1371/journal.pone.0027445 (autores: Kilimnik G et al.), sob licença da Creative Commons.

Quadro 14.3 - Terapia celular da diabetes melito: realidade ou ficção?

0 tratamento atual da diabetes melito envolve reposição hormonal com insulina, o qual não é capaz de manter um controle completamente eficiente da glicemia resultando em complicações clínicas em longo prazo. Nas últimas décadas, 0 transplante de pâncreas ou 0 transplante duplo de pâncreas e rim tem sido o tratamento mais efetivo de pacientes diabéticos graves; porém, em função da falta de órgãos disponíveis para transplante, do risco da própria cirurgia e da possibilidade de rejeição do orgão transplantado, novas alternativas terapêuticas, mais 
eficientes e menos invasivas, têm sido propostas, incluindo a terapia celular. Uma dessas alternativas, que tem sido utilizada com certo sucesso na clínica, é o transplante de ilhotas pancreáticas isoladas de cadáveres. ${ }^{22}$ As ilhotas são isoladas enzimaticamente do pâncreas exócrino e mantidas em cultura até o momento do transplante. Mas como as células beta diferenciadas não se dividem em cultura, o fator limitante do emprego do transplante de ilhotas como estratégia terapêutica continua sendo a disponibilidade de órgãos. Então, os avanços na terapia celular da diabetes têm focado na obtenção de uma fonte renovável de células produtoras de insulina e responsivas à glicose. 0 uso de células tronco embrionárias humanas (CTEh) tem atraído muita atenção por causa do potencial pluripotente dessas células e da facilidade de expansão dessas células em cultura. ${ }^{22}$ Entretanto, existem várias limitações no emprego das (TEh como ferramentas terapêuticas tais como: 1) falta de métodos confiáveis para induzir a diferenciação dessas células em células beta terminalmente diferenciadas em condições in vitro; 2) dificuldade em separar a população de células diferenciadas das células progenitoras; e 3) a impossibilidade de se controlar o destino das CTEh uma vez transplantadas ou, de induzir sua diferenciação in vivo. Entretanto, alguns grupos de pesquisa tem reportado a obtenção de células beta a partir de CTEh usando procedimentos que mimetizam as etapas de organogênese do pâncreas endócrino, tais como: 1) formação do endoderma através da estimulação das (TEh com ativina A (um membro da família do fator de crescimento transformante ß) e Wnt3a (membro da família da Wnts, proteínas secretadas e envolvidas em vários eventos da embriogênese); 2) sua diferenciação em epitélio pancreático (que expressa a proteína marcadora pancreática, Pdx1) através do tratamento com ciclopamina, um inibidor da via de sinalização mediada pelo Hedgehog; e 3 ) a indução da diferenciação dessas células progenitoras pancreáticas positivas para $\mathrm{Pdx} 1$ em células da linhagem endócrina. ${ }^{22} 0$ resultado desse protocolo foi a obtenção de células endócrinas pancreáticas (incluindo a célula beta), mas não terminalmente diferenciadas (imaturas).

0 uso de células precursoras pancreáticas isoladas de pacientes tem sido sugerido como uma possivel solução para obtenção de células beta responsivas à glicose e evitar-se problemas imunológicos desencadeados pela terapia celular. Entretanto, o principal problema com esse procedimento é que células fonte adultas são raras e difíceis de expandir em cultura. Tem sido também sugerido o emprego de células fontes derivadas de outros tecidos/órgãos (como as células ovais do fígado, as células do cordão umbilical, da placenta ou da medula óssea) no tratamento celular da diabetes, mas estudos nessa linha de investigação ainda são preliminares e inconclusivos quanto à sua aplicabilidade clínica.

\section{AGRADECIMENTOS}

Os autores agradecem à Profa. e dra. Cecília A. E. Escanhoela (Departamento de Anatomia Patológica, FCM, UNICAMP) por fornecer material histológico de fígado humano. 


\section{REFERÊNCIAS BIBLIOGRÁFICAS}

1. GITTES, G. K. Developmental biology of the pancreas: a comprehensive review. Dev. Biol., v. 326, p. 4-35, 2009.

2. SI-TAYEB, K.; LEMAIGRE, F. P.; DUNCAN, S. A. Organogenesis and development of the liver. Dev. Cell, v. 18, p. 174-189, 2010.

3. JUNQUEIRA, L. C. U.; CARNEIRO, J. Histologia Básica. 11 ed. Rio de Janeiro: Guanabara Koogan, 2008.

4. KIERSZENBAUM, A. L. Histologia e Biologia Celular. Uma introdução à patologia. 3 ed. São Paulo: Elsevier, 2012.

5. MCCUSKEY, R. S. The Hepatic Microvascular system in health and its response to toxicants. Anat. Rec., v. 291, p. 661-671, 2008.

6. VINKEN, M.; PAPELEU, P.; SNYKERS, S.; DE ROP, E.; HENKENS,T.; CHIPMAN, J. K.; ROGIERS, V.; VANHAECKE, T. Involvement of cell junctions in hepatocyte culture functionality. Crit. Rev. Toxicol., v. 36, p. 299-318, 2006.

7. JASKIEWICZ, K.; RZEPKO, R.; SLEDZINSKI, Z. Fibrogenesis in fatty liver associated with obesity and diabetes mellitus type 2. Dig. Dis. Sci., v. 53, p. 785-788, 2008.

8. STRAZZABOSCO, M.; FABRIS, L. Functional anatomy of normal bile ducts, Anat. Rec., v. 291, p. 653-660, 2008.

9. DUNCAN, A. W.; DORRELL, C.; GROMPE, M. Stem cells and liver regeneration. Gastroenterology, v. 137, p. 466-481, 2009.

10. SANTONI-RUGIU, E.; JELNES, P.; THORGEIRSSON, S. S.; BISGAARD, H.C. Progenitor cells in liver regeneration: molecular responses controlling their activation and expansion. APMIS, v. 113, p. 876-902, 2005.

11. WILLIAMS, J. A. Regulation of pancreatic acinar cell function. Curr. Opin. Gastroenterol., v. 22, p. 498-504, 2006. 
12. GAISANO, H. Y. A Hypothesis: SNARE-ing the mechanisms of regulated exocytosis and pathologic membrane fusions in the pancreatic acinar cell. Pancreas, v. 20, p. 217-226, 2000.

13. CRIDDLE, D. N.; MCLAUGHLIN, E.; MURPHY, J. A.; PETERSEN, O. H.; SUTTON, R. The pancreas misled: signals to pancreatitis. Pancreatology, v. 7, p. 436-446, 2007.

14. LEUNG, P. S.; IP, S. P. Pancreatic acinar cell: its role in acute pancreatitis. Int. J. Biochem. Cell Biol., v. 38, p. 1024-1030, 2006.

15. STEWARD, M. C.; ISHIGURO, H. Molecular and cellular regulation of pancreatic duct cell function. Curr. Opin. Gastroenterol., v. 25, p. 447-453, 2009.

16. MASAMUNE, A.; WATANABE, T.; KIKUTA, K; SHIMOSEGAWA, T. Roles of pancreatic stellate cells in pancreatic inflammation and fibrosis. Clin. Gastroenterol. Hepatol., v. 7, p. S48-54, 2009.

17. STANGER, B. Z.; DOR, Y. Dissecting the cellular origins of pancreatic cancer. Cell Cycle, v. 5, p. 43-46, 2006.

18. CABRERA, O.; BERMAN, D. M.; KENYON, N. S.; RICORDI, C.; BERGGREN, P.-O.; CAICEDO, A. The unique cytoarchitecture of human pancreatic islets has implications for islet cell function. Proc. Natl. Acad. Sci. U S A, v. 103, p. 334-9, 2006.

19. GEPTS, W.; LECOMPTE, P. M. The pancreatic islets in diabetes. Am. J. Med., v. 70, p. $105-115,1981$.

20. COllares-BuZATO, C. B. Junções Celulares. In: CARVAlHO, H. F.; RECCO-PIMENTEL, S. M. A Célula. São Paulo: Manole, 2007.

21. BARRETO, S. G.; CARATI, C. J.; TOOULI, J.; SACCONE, G. T. The isletacinar axis of the pancreas: more than just insulin. Am. J. Physiol. Gastrointest. Liver Physiol., v. 299, p. G10-22, 2010.

22. HORI, Y. Insulin-producing cells derived from stem/progenitor cells: therapeutic implications for diabetes mellitus. Med. Mol. Morphol., v. 42, p. 195-200, 2009. 